\title{
Environmental valuation using bargaining games: an application to water*
}

\author{
Margarita Gáfaro ${ }^{\dagger}$ and César Mantilla $a^{\ddagger}$
}

April 24, 2021

\begin{abstract}
We characterize a general bargaining game useful for environmental valuation purposes. In this game, a jointly endowed asset is divisible into smaller units of two types: those with and without an associated costly attribute. Bargaining parties can use monetary transfers to their counterpart in exchange for accruing more units of the jointly endowed asset. We show that the cost of the attribute is perfectly absorbed by the transfer in a broad set of game solutions. Outcomes differing in the allocation of the units with the costly attribute allows us to identify whether the players' valuation of the attribute corresponds to its value induced in the game (i.e., its cost) or whether this attribute is over-or under-valued. We show an application to the valuation of water in a lab-in-the-field experiment conducted with Colombian farmers. We find evidence that the players' valuation of in-plot access to water dwells between 2.1 and 3.5 times its induced cost in the experiment.
\end{abstract}

Keywords: lab-in-the-field experiment; cooperative bargaining; non-cooperative bargaining; Nash bargaining;

JEL classification: C78, C90, Q51

${ }^{*}$ Comments from Juan Camilo Cárdenas, Fredrik Carlsson, Juan Esteban Carranza, Nicolai Kuminoff, Jorge Maldonado, and from seminar participants in RIDGE-Environmental Economics, BEBES and Universidad Javeriana were of invaluable help. We gratefully acknowledge research assistance by Paola Poveda, Leonel Criado, Steffanny Romero, Cristhian Contreras, Natalia Moreno, and Yenny Mora, as well as the fieldwork coordination by Julián Pico and fieldwork assistance by Felipe Coy, Natalia Delgado, Brayan Díaz, Lukas Muñoz and Jacqueline Santos. Financial Support from the program "Inclusión productiva y social: programas y políticas para la promoción de una economía formal, código 60185, que conforma la Alianza EFI, bajo el Contrato de Recuperación Contingente No. FP44842-220-2018." is gratefully acknowledged.

${ }^{\dagger}$ Banco de la República de Colombia, Carrera 19 \#34-93, Bucaramanga (Colombia), mgafargo@banrep.gov.co.

${ }^{\ddagger}$ Economics Department, Universidad del Rosario, Calle 12C \#4-69, Bogotá (Colombia), cesar.mantilla@urosario.edu.co. 


\section{Introduction}

Stated preferences methods for environmental valuation are subject to an intense debate around how valid are hypothetical responses in the absence of markets (Diamond and Hausman, 1994; Smith and Osborne, 1996; Carson et al., 2001; Adamowicz, 2004; Schläpfer, 2006; Barrio and Loureiro, 2010; Carson, 2012; Hausman, 2012). The criticisms, mostly related to contingent valuation methods, are linked to the identification of systematic biases. Although the gap between willingness to accept (WTA) and willingness to pay (WTP) is perhaps the most familiar (Brown and Gregory, 1999; Knetsch, 2007; Tunçel and Hammitt, 2014; Kim et al., 2015), other biases include embedding, question order, context-dependence and anchoring (Vatn, 2004; Carlsson, 2010).

The identification of such biases is essential in the understanding of preferences and choices and, more importantly, on the refinement of valuation instruments Adamowicz, 2004; Harrison, 2006). Experimental Economics has contributed to the refinement of valuation methods by shedding light on the participants' understanding of the preference elicitation mechanism, the framing and context of the elicitation of value, the motives behind economic transactions, and the role of cheap talk in eliminating hypothetical biases (Cummings and Taylor, 1999; Bulte et al., 2005; Plott and Zeiler, 2005; Shogren, 2005; Harrison, 2006).

In this paper, we propose another application of incentivized economic experiments to environmental valuation. We introduce a general bargaining game with three specific properties that allow us to identify whether, on average, an attribute with an induced cost in the game is over-or under-valued by the participants. Since the context of the game is a bargaining situation, it can be applied when measuring the use value of environmental goods with a considerable degree of rivalry or with property rights that are poorly defined. We present an application to irrigation water with a sample of farmers in the Northeast of Colombia. This is a context lacking formal water markets, where farmers face credit and liquidity constraints, and where the lack of well-defined property rights increases the notion of rivalry over the irrigation prospects (Moreno-Sanchez et al., 2012).

The proposed bargaining game has the following properties: (i) two players are jointly endowed with a good that is divisible into smaller units, (ii) at least one of these units possess an attribute having an associated cost $F$ per unit, and (iii) both bargaining parties can use monetary transfers, from an individually endowed stock of tokens, in exchange for accruing a larger share of the jointly endowed good. These properties can be linked to a valuation exercise by framing the units with the cost $F$ as having (or lacking) an attribute of interest. Suppose two identical allocations, except by the holder of the unit with the costly attribute. The transfers between these allocations should differ only on the cost imposed by this attribute, $F$. If the transfers differ in an amount larger (resp. lower) than $F$, we have evidence of the attribute's overvaluation (resp. undervaluation).

Let us introduce a simple example. Imagine that two players, A and B, are jointly endowed with three lottery tickets. Two tickets are blue, and one is red. Each player also receives an individual endowment of $\$ 5$. One of the three tickets will be selected as the winner, giving a $\$ 12$ prize to its holder. All tickets are equally likely to win, but the holder of the red ticket has to pay a participation fee of $\$ 2$ before drawing the winning ticket. The two players must agree on how to split the tickets; otherwise, the three tickets are discarded, and each player keeps her endowment. Any fraction of the endowment can be used to make 
a transfer to the other player in exchange for accruing more tickets.

This game meets the three properties listed above. Players are jointly endowed with an "asset" that is divisible in three tickets. One ticket has an attribute, the red color, associated with a cost of $F=\$ 2$. Both players receive a fixed endowment that they can use to offer a transfer and reach an agreement regarding an allocation of tickets. Our interest dwells in the two allocations where player A holds a given number of lottery tickets but vary in the holder of the red ticket, the costly asset. For instance, it is straightforward to see the equivalence between the following allocations:

- Player A keeps the two blue tickets and she transfers $\$ 3$ to Player B

- Player A keeps one blue and one red ticket and she transfers $\$ 1$ to Player B

In essence, the holder of the red ticket must pay $F=\$ 2$. Since the transfer and the cost $F$ are additive, players $\mathrm{A}$ and $\mathrm{B}$ should be indifferent between the two alternatives once the transfer from the latter allocation is reduced in $F=\$ 2$. Thus, the presence or absence of the "red" attribute can be offset by adjusting the offered transfer. As color is an abstract attribute, one would not expect any emotional attachment or other context-specific preferences that will induce a deviation from $\$ 2$ in players' valuation of the blue over the red ticket. By contrast, if the differential attribute evokes players' preferences beyond its direct use in the game, one might observe deviations from $F$ between the average transfers from two allocations differing only on who pays for holding the costly attribute.

The contribution of the bargaining games proposed in this paper dwells on the disparities between "homegrown values" and "induced values" (Harrison, 2006) as a tool for measuring over(under) valuation. In framed and lab-in-the-field experiments, the costly attribute ${ }^{1}$ might be linked to context-specific values or elements from the participant's identity (Cárdenas and Ostrom, 2004). We argue that this is the case for irrigation water in our application. Our experimental framing describes a bargaining situation involving the division of a farm in which some land abuts a water stream. ${ }^{2}$ The jointly endowed farm is divided into irrigated and non-irrigated land plots. This feature allows us to introduce the costly attribute as water conveyance in the non-irrigated plots. We use the differences in the average transfers between two almost identical land configurations, differing only in the allocation of the marginal irrigated tile, and show that rural participants in the experiment value in-plot access to water between 2.1 and 3.5 times its induced value in the game.

This application contributes to the environmental valuation literature in developing countries. The use of contingent valuation techniques has been challenging in these contexts partly due to low levels of measured WTP for environmental services (Whittington, 2002, 2010; Whittington and Pagiola, 2012). This low WTP might understate individual valuation. Low levels of disposable income and the mistrust that the collected payments will be efficiently targeted to the service provision might bias elicited valuations downwards (Ahlheim and Lehr, 2008; Whittington and Pagiola, 2012; Weldesilassie et al., 2009).

\footnotetext{
${ }^{1}$ Whereas choice experiments are suited for multi-attribute valuation Boxall et al. 1996 , Johnston et al. 2017), we emphasize our capability to identify the over(under) valuation of a single attribute.

${ }^{2}$ In Gáfaro and Mantilla (2020), we use the same experimental design, plus an augmented sample, to test whether preferences for egalitarian land divisions drive agreements away from efficiency.
} 
Small scale implementations of our bargaining game might help overcome these challenges (i.e., in pre-testing sessions for valuation instruments applied at a broader scale). The endowment used in monetary transfers in the game is orthogonal to real wealth, allowing us to disentangle preferences from liquidity constraints. Moreover, it can provide information on use values from goods or services where property rights are contested between the two players. Therefore, the lack of trust in institutions should not interfere with our measurement. The joint ownership in our bargaining setting also mitigates biases associated with an endowment effect, as offers are not initially reflecting either a WTP or a WTA Knetsch, 1989; Kahneman et al., 1990).

As a more general contribution, the use of bargaining games in the field, other than the ultimatum, is rare (Henrich et al., 2001, 2004, Gurven et al., 2008). The game proposed in this paper has a broader range of applications, as it departs from a more general bargaining framework. This advantage becomes evident in two practical aspects. First, it allows introducing an endogenous surplus, an important feature to connect bargaining games with welfare analysis. Second, bargaining parties can be asymmetric. This expands the range of framing options within the game and let us focus on the predictions for one of the roles, if needed.

Our application, involving in-plot irrigation among Colombian farmers, also contributes to understanding of water valuation in developing countries. The development of formal water markets faces obstacles, including the lack of well-defined property rights, credit and liquidity constraints, and ineffective contract enforcement Abramson et al., 2011; Foster and Sekhri, 2008). Moreover, direct estimates of demand, when markets exist, can underestimate the WTP for water due to credit and liquidity constraints (Abramson et al., 2011; Devoto et al. 2012), distortionary subsidies (Perfetti et al., 2019; Whittington and Pagiola, 2012), coordination problems in communal irrigation facilities (Nauges and Whittington, 2010), and protest responses due to perceptions of low-quality provision (Jorgensen et al., 1999; Meyerhoff and Liebe, 2006). Besides, valuation studies of water resources in developed countries often involve uses with a low degree of rivalry: preservation of endangered species, provision of ecosystem goods and services, and recreational uses of water bodies (Loomis, 2000; Greenland-Smith et al., 2016; De Groot et al., 2012). By contrast, access to irrigation water in developing countries involves a high degree of rivalry and large heterogeneities across users (Jack, 2009; Janssen et al., 2012; Moreno-Sanchez et al., 2012).

Empirical evidence about differences in the intensity of use and marginal returns to water, across and within regions, suggests the existence of inefficiencies in the allocation of water in developing countries (Jacoby et al., 2004; Kumar et al., 2008). If the water source is not directly available on the farm, access is costly due to conveyance losses, large fixed infrastructure investments, and imperfect contract enforcement in informal arrangements with water providers. For plot owners, direct access to water does not only increase agricultural production (Kumar et al., 2008; Duflo and Pande, 2007), but also provides opportunities of generating additional income by informally selling other farmers the right to extract water (Banerji et al., 2012), and by allowing them to avoid disputes over water access (Sekhri, 2014).

Consistent with this evidence, we show that in a bargaining game of land allocation, players reveal a valuation of in-plot irrigation that exceeds the irrigation costs induced in the game. We find that this overvaluation is likely to be driven by the behavior of participants 
in regions with water scarcity.

The rest of the paper is organized as follows. In Section 2, we present the general bargaining model. We show a direct relationship between the monetary transfer and the allocation of the costly attribute, regardless of whether the bargaining problem is modeled as a cooperative or a non-cooperative interaction. In Section 3, we introduce our application of the bargaining game for water valuation. We explain the game, emphasizing how we can measure the valuation of irrigated land plots relative to the non-irrigated plots, even if the game was primarily conceived for studying the determinants of land division. Section 4. describes our sampling and how the game was conducted. In Section 5, we show that the value of irrigated plots relative to non-irrigated plots exceeds the irrigation costs in the experiment. Section 6, concludes with a discussion of potential applications and challenges of bargaining games in environmental valuation.

\section{A bargaining model for attribute's valuation}

We start this section by introducing a general bargaining game. Players must agree on how to allocate two jointly endowed assets that are heterogeneous in their costs. Players are endowed with a stock of tokes that they can use to reach an agreement. We show that the allocation of tokens adjusts to compensate differences in the allocation of the costly asset. This is true for the cooperative solution, in which players decide how to share the surplus an agreement (Roth and Malouf, 1979); and for the non-cooperative solution, in which a player submitting a final take-it-or-leave-it offer extracts most of the rents from the agreement (Rubinstein, 1982).

\subsection{General framework}

Two players denoted by subscript $i=\{1,2\}$ bargain over the allocation of $E_{x}$ and $E_{y}$ units of two types of assets $x$ and $y$. Let $x_{i}$ and $y_{i}$ be the units of each asset that are allocated to Player $i$, and $\nu\left(x_{1}+y_{1}\right)$ and $\mu\left(x_{2}+y_{2}\right)$ the returns of the assets for Players 1 and 2 , respectively.

Assumption 1: The returns functions $\nu$ and $\mu$ are continuous and twice differentiable functions with $\nu^{\prime}>0, \mu^{\prime}>0, \nu^{\prime \prime}<0$, and $\mu^{\prime \prime}<0$,

Each unit of asset $y$ entails a cost $F$ to its holder. Each player has an endowment of tokens $E_{T}$ that she can use to make a transfer to the other player when bargain over an asset allocation. We denote by $T>0$ a transfer from Player 1 to Player 2 , and $T<0$ a transfer from Player 2 to Player 1. Players' payoffs from an agreement $\left(x_{1}, x_{2}, y_{1}, y_{2}, T\right)$ are given by

$$
\begin{aligned}
& W_{1}\left(x_{1}, y_{1}, T\right)=\nu\left(x_{1}+y_{1}\right)-F y_{1}-T+E_{T}, \\
& W_{2}\left(x_{2}, y_{2}, T\right)=\mu\left(x_{2}+y_{2}\right)-F y_{2}+T+E_{T} .
\end{aligned}
$$

Let $d_{1}$ and $d_{2}$ be fixed disagreement payoffs. 
Assumption 2: The disagreement payoffs, the endowments, and the attribute's cost are such that bargaining is individually beneficial. That is, there exist an allocation $\left(x_{1}, y_{1}\right)$ and a transfer $T$ such that $x_{1} \leq E_{x}, y_{1} \leq E_{y},|T| \leq E_{T}, \nu\left(x_{1}+y_{1}\right)-F y_{1}-T+E_{T}>d_{1}$, and $\mu\left(E_{x}+E_{y}-x_{1}-y_{1}\right)-F\left(E_{y}-y_{1}\right)+T+E_{T}>d_{2}$. Moreover, both players derive positive net returns from the costly asset, $F<\nu^{\prime}(z)$ and $F<\mu^{\prime}(z)$ for any $z<E_{x}+E_{y}$.

\subsection{Cooperative solution}

The Nash bargaining solution $\left(x_{1}^{*}, x_{2}^{*}, y_{1}^{*}, y_{2}^{*}, T_{C}^{*}\right)$ satisfies

$$
\begin{gathered}
\max \left(\nu\left(x_{1}+y_{1}\right)-F y_{1}-T+E_{T}-d_{1}\right)^{p}\left(\mu\left(x_{2}+y_{2}\right)-F y_{2}+T+E_{T}-d_{2}\right)^{2-p} \\
\text { s.t. } \\
x_{1}+x_{2} \leq E_{x} \\
y_{1}+y_{2} \leq E_{y} \\
|T| \leq E_{T}
\end{gathered}
$$

where $p \in(0,2)$ represents the relative bargaining ability of Player 1 .

In what we present next, we focus on the solution to the maximization problem in Equation 1 when the token endowment constraint is not binding. We show that, when this is the case, there is a direct correspondence between the allocation of the costly asset and the transfer ${ }^{3}$ From the first order conditions with respect to $x_{1}$ and $y_{1}$, we can see that any $x_{1}^{*}$ and $y_{1}^{*}$ that satisfy $\nu^{\prime}\left(x_{1}^{*}+y_{1}^{*}\right)=\mu^{\prime}\left(E_{x}+E_{y}-x_{1}^{*}-y_{1}^{*}\right)$ are interior solutions.

Let $z_{1}=x_{1}+y_{1}$ be the total amount of assets of Player 1 . For a given $z_{1}$, the player holding a larger share of the costly asset $y$ can be directly compensated through a transfer $T$. For example, Player 1 can increase her transfer by $F$ tokens in exchange for accruing one more unit of $x$ rather than one more unit of $y$. Thus, we can characterize the interior solution to the Nash Bargaining problem by an equilibrium allocation of total assets, $z_{1}^{*}$, and an $F$-absorbing transfer, $\hat{T}_{C}^{*}$, that solves

$$
\left(z_{1}^{*}, \hat{T}_{C}^{*}\right)=\arg \max \left(\nu\left(z_{1}\right)-\hat{T}+E_{T}-d_{1}\right)^{p}\left(\mu\left(E_{x}+E_{y}-z_{1}\right)-F E_{y}+\hat{T}+E_{T}-d_{2}\right)^{2-p},
$$

where $\hat{T}=T+F y_{1}$ (i.e., $\hat{T}$ directly captures, or absorbs, the attribute's cost $F$ from the costly asset). In equilibrium, the $F$-absorbing transfer $\hat{T}_{C}^{*}$ is given by

$$
\hat{T}_{C}^{*}=\frac{1}{2}\left[(2-p)\left(\nu\left(z_{1}^{*}\right)+E_{T}-d_{1}\right)-p\left(\mu\left(E_{x}+E_{y}-z_{1}^{*}\right)-F E_{y}+E_{T}-d_{2}\right)\right],
$$

where $z_{1}^{*}$ satisfies

$$
\nu^{\prime}\left(z_{1}^{*}\right)=\mu^{\prime}\left(E_{x}+E_{y}-z_{1}^{*}\right)
$$

\footnotetext{
${ }^{3}$ Note that in the corner solution, when the token constraint is binding, the token transfer cannot fully adjust to variations in the distribution of the costly asset.
} 
The equilibrium transfer perfectly absorbs the effect of the attribute's cost, $F$, on players' payoffs. A larger bargaining ability of Player 1 results in a lower equilibrium transfer or, equivalently, in a lower share of the costly asset. To see this, note that for any $x_{1}^{*}$ and $y_{1}^{*}$ that satisfy $z_{1}^{*}=x_{1}^{*}+y_{1}^{*}$, the equilibrium transfer is

$$
T_{C}^{*}=\frac{1}{2}\left[(2-p)\left(\nu\left(z_{1}^{*}\right)+E_{T}-d_{1}\right)-p\left(\mu\left(E_{x}+E_{y}-z_{1}^{*}\right)-F E_{y}+E_{T}-d_{2}\right)\right]-F y_{1}^{*}
$$

In equilibrium, one additional unit of the costly asset held by Player 1, keeping her total amount of assets constant $\left(z_{1}^{*}\right)$, results in a decrease in the transfer of $F$ units.

$$
\frac{\partial T_{C}^{*}}{\partial y_{1}^{*}}=-F
$$

\subsection{Non-cooperative solution}

We now explore the cooperative solution to the game if Player 2 can make a take-it or leave-it offer to Player 1 about an asset allocation and a transfer ${ }^{4}$ If Player 1 rejects the offer, both players get their disagreement payoffs $d_{1}$ and $d_{2}$.

The equilibrium allocation in this non-cooperative framework $\left(x_{1}^{*}, x_{2}^{*}, y_{1}^{*}, y_{2}^{*}, T_{N C}^{*}\right)$ is characterized by

$$
\begin{array}{r}
\left(x_{1}^{*}, x_{2}^{*}, y_{1}^{*}, y_{2}^{*}, T_{N C}^{*}\right)=\arg \max W_{2}\left(x_{2}, y_{2}, T\right) \\
\text { s.t. } \\
\\
W_{1}\left(x_{1}, y_{1}, T\right) \geq d_{1} \\
x_{1}+x_{2} \leq E_{x} \\
y_{1}+y_{2} \leq E_{y} \\
|T| \leq E_{T}
\end{array}
$$

By assumptions 1 and 2, the asset endowment constraint and the participation constraint of Player 1 are satisfied with equality. As before, if we focus on the case when the token endowment constraint is not binding, we can solve for the total allocation of the total assets, $z_{1}$, and the $F$-absorbing transfer, $\hat{T}_{N C}$, maximizing the function

$$
\mathcal{L}=\mu\left(E_{x}+E_{y}-z_{1}\right)-F E_{y}+\hat{T}_{N C}+E_{T}-\lambda\left(d_{1}-\nu\left(z_{1}\right)+\hat{T}-E_{T}\right) .
$$

In the interior solution, $z_{1}^{*}$ satisfies Condition 2 and $\hat{T}_{N C}^{*}=\nu\left(z_{1}^{*}\right)-d_{1}+E_{T}$.

As before, any $x_{1}^{*}$ and $y_{1}^{*}$ that satisfy $x_{1}^{*}+y_{1}^{*}=z_{1}^{*}$ are equilibrium allocations in the non-cooperative solution, and

$$
T_{N C}^{*}=\nu\left(z_{1}^{*}\right)-d_{1}+E_{T}-F y_{1}^{*} .
$$

\footnotetext{
${ }^{4}$ For brevity, we present the case in which Player 2 makes the final offer, but the solution will be identical for Player 1 having this advantageous position.
} 
If $z_{1}^{*}$ is held constant and Player 1 accrues one more costly unit, the transfer is adjusted in exactly the cost of a unitary change in $y_{1}^{*}$. That is,

$$
\frac{\partial T_{N C}^{*}}{\partial y_{1}^{*}}=-F
$$

Equations 4 and 5 imply that, regardless of whether participants engage in cooperative or non-cooperative bargaining, the optimal transfer adjusts according to the allocation of the costly asset. In the next section, we show that this relationship holds for more general solutions to the game.

\subsection{Generalization}

In this section, we present a more general response function for the token transfer. We show that the relationship between the allocation of the costly asset and the transfer holds for a broad set of solution concepts that can be expressed as an optimization problem, and for every feasible allocation of total assets $\left(z_{1}, z_{2}\right)=\left(x_{1}+y_{1}, x_{2}+y_{2}\right)$.

Proposition 1: If for any asset allocation $\left(z_{1}, z_{2}\right)$, we can write the equilibrium transfer $T\left(z_{1}, y_{1}\right)$ as the interior solution of

$$
\max _{T} G\left(W_{1}\left(z_{1}, y_{1}, T\right), W_{2}\left(z_{1}, y_{2}, T\right)\right)
$$

where

$$
\begin{array}{r}
W_{1}\left(z_{1}, y_{1}, T\right)=\nu\left(z_{1}\right)-F y_{1}-T+E_{T} \\
W_{2}\left(z_{2}, y_{2}, T\right)=\mu\left(z_{2}\right)-F y_{2}+T+E_{T} \\
y_{1}+y_{2}=E_{y} \\
x_{1}+x_{2}=E_{x}
\end{array}
$$

then,

$$
\frac{\partial T\left(z_{1}, y\right)}{\partial y}=-F
$$

In the Appendix, we show that Equation 7 follows from applying the Implicit Function Theorem to the First Order Condition of the maximization problem in Equation 6. Note that the cooperative and non-cooperative solution presented above are special cases of Equation 6. when $z_{1}$ satisfies Condition 2, This generalization is relevant because the transfer, when offsetting the attribute's cost, is a best-response to an out-of-equilibrium reallocation between costly and non-costly asset units. 
Figure 1: Plot configuration in the bargaining game.

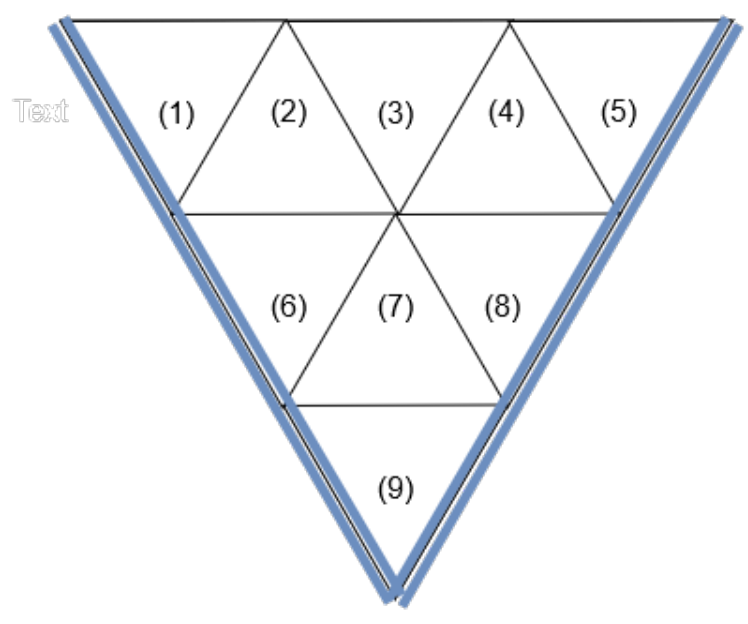

\section{Application: water valuation in a land division game}

\subsection{General setup}

Two players, $H$ and $L$, are jointly endowed with a farm plot divided into nine triangular tiles of the same size, as shown in Figure 1. Each player also receives an endowment $e$ of 10 tokens that she can offer to her counterpart in exchange for keeping more land tiles. At the end of the game, each land tile grants a die roll simulating a realization of a stochastic plot yield. Player $H$ is more productive with each tile, and her dice faces are marked as $\{3,3,4,4,5,5\}$; whereas Player $L$ 's dice faces are marked as $\{2,2,3,3,4,4\}$. The dice configurations are common information, allowing players to know the expected differences in productivity. However, the realized dice roll is private information for each player, minimizing the role of ex-post risk-sharing agreements unobserved by the researcher.

Players bargain over an allocation of land plots $\left[\ell_{H}: \ell_{L}\right]$ and a token transfer $T$ in a negotiation with two phases. First, an explicit bargaining phase with face-to-face communication for 5 minutes. Second, a structured bargaining phase. In this phase, Player $H$ makes a written offer to Player $L$. If Player $L$ rejects this offer, she can make a take-it or leave-it counter-offer. If Player $H$ rejects the counter-offer, we implement a disagreement outcome, leaving each player with her endowed tokens and four land tiles (i.e., the ninth tile is lost). At the end of the game, each players' agricultural profits and tokens are converted into monetary earnings.

\subsection{Land Configuration and Costs}

Land tiles are heterogeneous in a dimension that simulates the in-plot availability of irrigation water. Figure 1 depicts two thick double lines on the left and right sides of the plot. These lines represent a water stream. The land plots that share at least one side with the stream have direct access to water. Irrigation for agricultural production is costless in 
these tiles. We refer to these as irrigated land tiles. Agricultural production in non-irrigated tiles, numbered (2), (3), (4), and (7), have a cost of 1 , aiming to simulate the irrigation costs. By denoting the set of non-irrigated tiles of Player $i$ as $N_{i}$, total irrigation costs for Player $i$ are given by $c^{I_{i}}=\sum_{k=1}^{\ell_{i}} \mathbb{1}\left\{k \in N_{i}\right\}$.

Besides irrigation costs, the game includes border costs, defined as follows. Any tile from Player $i$ adjacent to a tile from her counterpart is defined as a "border tile" and generates a cost of 1 to its owner. Total border costs for Player $i$ are given by the number of border tiles $B_{i}$ that she holds $c^{B_{i}}=\sum_{k=1}^{\ell_{i}} \mathbb{1}\left\{k \in B_{i}\right\}$. The purpose of border costs is to reinforce the inefficiencies from land divisions, explored in Gáfaro and Mantilla (2020).

\subsection{Payoffs}

Monetary payoffs $m_{i}$ for player $i$ depend on the realization of total agricultural output in her $\ell_{i}$ tiles, $Y_{i}^{\ell_{i}}$; the token endowment, the transfer $T$, and the irrigation and border costs, $c^{I_{i}}$ and $c^{B_{i}}$.

$$
\begin{gathered}
m_{H}\left(Y_{i}^{\ell_{H}}, T\right)=10-T+Y_{i}^{\ell_{H}}-c^{I_{H}}-c^{B_{H}} \\
m_{L}\left(Y_{i}^{\ell_{L}}, T\right)=10+T+Y_{i}^{\ell_{L}}-c^{I_{L}}-c^{B_{L}} .
\end{gathered}
$$

By convention, the transfer $T$ goes from Player $H$ to $L$. Positive (resp. negative) transfers represent a flow of tokens from player $H$ to $L$ (resp. $L$ to $H$ ). This explains the different sign of $T$ in Equations 8 and 9 .

Note that the transfer $T$ and the irrigation costs enter linearly in the payoffs functions. How $T$ adjusts to differences in the distribution of irrigated tiles gives us information about players' valuation of direct access to irrigation water. As we show in Section 2, the optimal transfer $T$ should adjust to exactly compensate the additional costs of holding non-irrigated land tiles. We claim that any deviation from this expected adjustment would give us information about players' preferences towards irrigated compared to non-irrigated plots.

If we assume that players' preferences over the alternatives in the game only depend on the game's payoffs, we can define the expected utility from an agreement with a land allocation $\left[\ell_{H}: \ell_{L}\right]$ and a transfer $T$ as

$$
v_{i}\left(\ell_{i}, T\right)=\sum_{s} \operatorname{Pr}\left(Y_{i}^{\ell_{i}}=s\right) u_{i}\left(m_{i}(s, T)\right)
$$

where $\operatorname{Pr}\left(Y_{i}^{\ell_{i}}=s\right)$ is the probability that the sum of all rolled dice of Player $i$ takes the value of $s$, and $u$ is a utility function that represents players' preferences. Similarly, we can define the expected utility from the disagreement by setting $T=0$ and deducting the irrigation and border costs from the endowment. We have:

$$
d_{i}=\sum_{s} \operatorname{Pr}\left(Y_{i}^{4}=s\right) u_{i}(s+6) .
$$

Gáfaro and Mantilla (2020) discuss three alternative solutions to this game, assuming a 
CRRA utility function with moderate levels of risk aversion 5 First, we show that if players agree to maximize their aggregate expected utility, Player $H$ accrues all the land tiles, while she gives all her tokens in exchange to Player $L$ (i.e., $T=10$ ). We also show that in the cooperative and non-cooperative solutions, discussed in Section 2, Player $H$ accrues between 7 and 9 tiles, and transfers all her tokens to Player $L$.

None of these three frameworks can predict the prevalence of egalitarian land allocations observed in the field, as $75 \%$ of bargaining pairs choose an allocation of land in which each player accrues at least 4 tiles. This discrepancy between the original predictions and the findings in the field is not inconvenient when exploring water valuation. We show in Section 2 that, due to the additivity between the transfer and the costs, any reallocation of assets results in a best-response function for the transfer that is linear in the costly asset. Moreover, the slope of this line is equal to the induced value of the asset in the game, $F$.

In the following subsection, we show that egalitarian land configurations differing only in the allocation of the marginal irrigated tile are also informative of players' valuation of the irrigation water.

\subsection{Land configurations in the egalitarian land allocations}

We will provide an intuitive explanation on how we measure valuation using the most egalitarian land allocations, [5:4] and [4:5]. Nonetheless, our model applies to all possible bargaining outcomes. We will include them in our econometric analysis.

Once we consider irrigated and non-irrigated tiles, there are two possible configurations for the [5:4] and [4:5] land allocations. To identify water over-or under-valuation, the critical element of analysis is how the configurations differ by exactly one irrigated tile, holding constant the total number of tiles. Panels (a) and (b) of Table 1 depict the case when player $H$ accrues five tiles. We list the expected payoffs for both players as a function of the stochastic production $Y_{i}^{\left[\ell_{i}\right]}$ and, in parenthesis, the non-random component resulting from the remaining endowment after the deduction of production costs plus the transfer.

In Panel (a), Player $H$ accrues three irrigated tiles and two non-irrigated tiles. Since this leaves Player $L$ with two non-irrigated plots, each player assumes an irrigation cost of $c^{I_{H}}=c^{I_{L}}=2$. We will call this configuration the Majority irrigated. In Panel (b), Player $H$ accrues two irrigated tiles, yielding a higher irrigation cost for her, with $c^{I_{H}}=3$ and $c^{I_{L}}=1$. We will call this configuration the Majority non-irrigated.

Note that Player $H$ can make her expected payoff identical between the configurations shown in panels (a) and (b) by lowering the offered transfer $T$ in one unit in the Majority non-irrigated, with respect to the Majority irrigated configuration. This equivalence is independent of the players' relative risk-aversion levels since the stochastic component in the payoff, $Y_{i}^{\left[\ell_{i}\right]}$, is not affected by irrigation costs and transfers. If this equivalence is met, we can argue that the players' valuation of the attribute of interest, in-plot irrigation, corresponds to the induced value from the experimenter's parameterization. By contrast, deviations from the induced value of in-plot irrigation can be interpreted as evidence of overvaluation (resp. undervaluation) when the difference in the average transfer between the Majority irrigated

\footnotetext{
${ }^{5}$ Average estimates of $\gamma$ tend to fall below one (Holt and Laury, 2002, Andersen et al., 2008; Andreoni and Sprenger, 2012
} 
(a) Majority of irrigated tiles

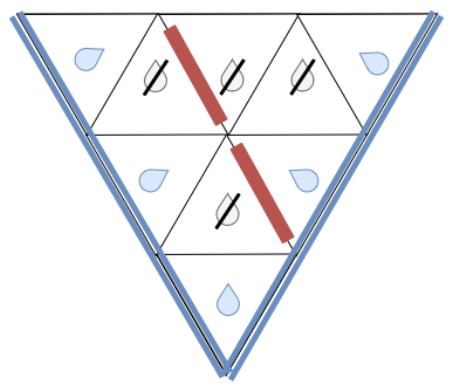

$$
\begin{aligned}
c^{I_{H}} & =2, c^{I_{L}}=2 \\
c^{B_{H}} & =2, c^{B_{L}}=2
\end{aligned}
$$

$[5: 4]$

$m_{H}=Y_{H}^{[5]}+(6-T)$

$m_{L}=Y_{L}^{[4]}+(6+T)$ (b) Majority of non-irrigated tiles

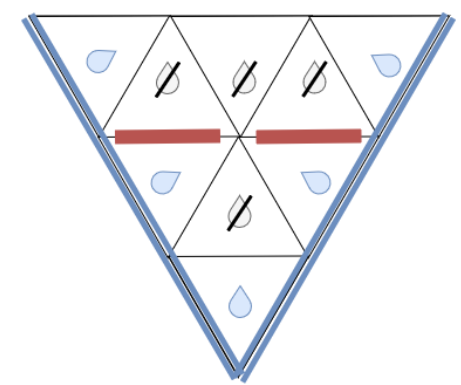

$$
\begin{aligned}
c^{I_{H}} & =3, c^{I_{L}}=1 \\
c^{B_{H}} & =2, c^{B_{L}}=2
\end{aligned}
$$

$[5: 4]$

$m_{H}=Y_{H}^{[5]}+(5-T)$

$m_{L}=Y_{L}^{[4]}+(7+T)$ (c) Disagreement outcome

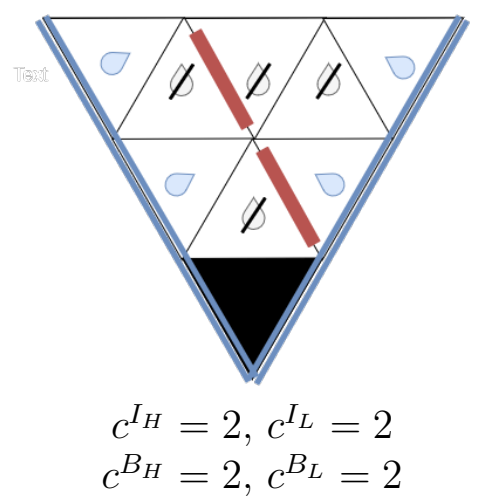

$$
\begin{gathered}
{[4: 4]} \\
m_{H}=Y_{H}^{[4]}+6 \\
m_{L}=Y_{L}^{[4]}+6
\end{gathered}
$$

Table 1: Configurations of irrigated and non-irrigated tiles in the egalitarian land allocation (panels a and b). Land configuration under the disagreement outcome (panel c).

and the Majority non-irrigated exceeds (resp. falls behind) the irrigation cost ${ }^{6}$

Panel (c) depicts the land configuration in case of a disagreement, as well as the associated payoffs. After eliminating one tile, the allocation of irrigated and non-irrigated tiles is egalitarian. Border and irrigation costs are also equally divided. Finally, each player keeps her endowment. The comparison between panels (a) and (c) makes evident that both players will be better off by reaching an agreement in which Player $L$ demands a positive transfer of at most four tokens-the expected productivity of this tile for Player $H$-in exchange for letting $H$ keep the ninth tile. A similar reasoning applies to the comparison between panels (b) and (c).

\section{Experimental set up}

\subsection{Sampling}

We conducted the experiment in eight rural municipalities in the Northeast of Colombia between September and November 2018. The selected municipalities differ in their access to markets (i.e., distance to the nearest city), the share of rural population, and agro-climatic conditions. There is also significant variation in the type of agriculture across the selected municipalities. In six of these municipalities, the largest share of planted areas corresponds to crops typically produced in small farms: coffee, cocoa, potato, tomato, and sugar cane. In

\footnotetext{
${ }^{6}$ For brevity, we do not describe in detail the scenario in which player $L$ accrues five tiles, but the reasoning is identical except that the transfer will go in the opposite direction, and the expected outcome is slightly less efficient in terms of agricultural yield.
} 
the other two municipalities, the largest shares of planted area correspond to African palm, a crop with significant economies of scale (see Table A.1 in the Appendix).

Water supply conditions also vary across the selected municipalities. Table A.1 presents the mean of yearly rainfall by municipality and two measures of water supply provided by the National Institute of Meteorology and Environmental Studies (IDEAM). In our empirical analysis, we use this variable to classify the municipalities in the sample across the median of availability during dry years and explore whether the relative abundance of water explains players' valuation of irrigated tiles.

The research team conducting the sessions consisted of a research coordinator and a field assistant. The same research coordinator conducted the sessions in all the municipalities. Nonetheless, there were several field assistants to make sure that at least a member was acquainted with the area before the visit. A local person was hired in each municipality to provide aid with the recruitment. The experiment was conducted over the weekends, when the rural population congregates in local market areas.

The initial rural sample account for 256 participants, 32 per municipality. However, half of the participants intervened in a treatment arm in which we cannot study whether water was overvalued because bargaining pairs were not allowed to divide the land plot. This restriction leaves us with 128 participants (64 bargaining pairs) for the analysis that we present below. Forty-nine percent of the participants are males, participants were on average 38 years old, $48 \%$ of them identified themselves as farmers, and $85 \%$ of them reported that their household owns land.

\subsection{Experimental Paradigm}

In this section, we explain in detail the execution of a session. It follows the general setup described in Section 3. The only relevant game variation relates to the attainable agricultural yield. In half of our sessions, we increased the uncertainty by doubling the spread of the dice outcomes for both players. Hence, under this alternative parameterization, Player $H$ 's dice had faces with the numbers $\{2,2,4,4,6,6\}$ and Player $L$ 's had $\{1,1,3,3,5,5\}$. Our purpose was to test whether higher uncertainty favored land division rules that depart from efficiency considerations in the game. Since we found that uncertainty does not affect land allocations when players are allowed to divide the land plot (Gáfaro and Mantilla, 2020), we will pool our experimental data in our analyses, regardless of the uncertainty condition. We control for the assignment of this treatment variation in our regression estimates.

Sessions had a maximum of four participants. Each session began with the field coordinator providing a brief introduction to the activity, and it proceeded as follows:

(i) Explanation of the jointly endowed plot. The field team delivered to each pair of participants a printed version of Figure 1. In the protocol, this is called the "map" of the jointly inherited land plot and explained that their objective was to find an agreement, in which they can use their tokens, to allocate the land tiles. The map was placed such that each participant was next to one of the blue sides (i.e., the water stream) to make sure that they had a symmetric view of the land plot. Irrigated tiles were marked with a blue drop of water and a " $+0 "$ indicating the null irrigation cost. Non-irrigated tiles were marked with a gray crossed drop of water and a "-1" corresponding to the irrigation cost (see Figure 2).

(ii) Random assignment of roles as Players $H$ and $L$. Participants rolled a plastic 
Figure 2: "Map", tokens and dice delivered to each bargaining pair of participants.

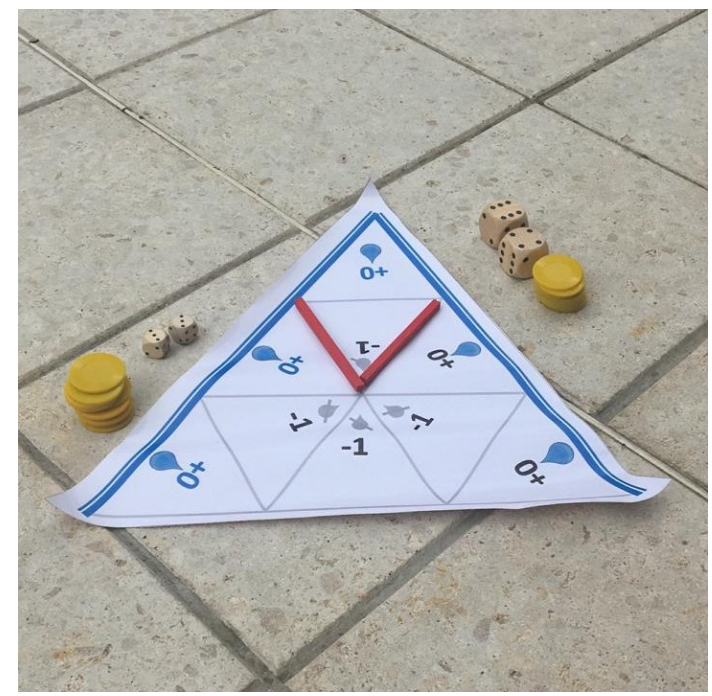

die, numbered from 1 to 6 , knowing that the participant with the highest number will be assigned to the role of Player $H$. To remark the asymmetry in their productivity, Player $H$ received a "big" wooden die $\left(27 \mathrm{~cm}^{3}\right)$, and Player $L$ received a "small" wooden die $\left(1 \mathrm{~cm}^{3}\right)$. Each die was marked with the potential outcomes. The participants were reminded that, at the end of the game, they would receive as many dices as accrued tiles, identical to the one in their hands.

(iii) Explanation of border tiles. The field team delivered to each bargaining pair a set of red wooden logs to mark the boundaries in case land was divided. The coordinator explained that each log would increase the production costs of each participant by one token.

(iv) Final instructions for the bargaining game. The coordinator provided a predefined example and announced that participants would have at most five minutes to reach a verbal agreement. Once time ran out, or if participants announced earlier that they had reached an agreement, they proceeded with the structured bargaining phase.

(v) Informed consent. Once participants confirmed they understood the instructions, they provided written consent for participating in the experiment and voice-recording the unstructured bargaining stage.

(vi) Bargaining phase.

(vii) Payoff calculation. Each participant was taken in private. She put inside a box as many dice as tiles she accrued according to the bargaining outcome. The participant was instructed to vigorously shake the box to "roll the dice" and make sure that her realized yield, and therefore her earnings, could not be observed by anyone else. The earnings were paid after completing a post-experimental survey.

The full experimental protocol is available in English and Spanish in Appendices A.3 and A.4. respectively. Each session lasted at most 60 minutes, and participants received on average $\$ 22,300( \pm 5,750)$ Colombian pesos (COP) $]^{7}$ Although the length of a session appears

\footnotetext{
${ }^{7} \mathrm{By}$ the time of the experiment, this average payment corresponded to roughly $7.2 \mathrm{USD}$, and it represents between 1.1 and 1.4 times the daily agricultural wage in the area of study.
} 
Table 2: Average Transfer for [5:4] and [4:5] Land Configurations: Rural Sample

\begin{tabular}{|c|c|c|c|c|}
\hline \multicolumn{2}{|r|}{ Land Division } & \multirow[t]{2}{*}{$\mathbf{N}$} & \multirow{2}{*}{$\begin{array}{c}\text { Mean } \\
\text { Transfer }\end{array}$} & \multirow{2}{*}{$\begin{array}{c}\text { Difference } \\
(p \text {-value })\end{array}$} \\
\hline$\left[\ell_{H}: \ell_{L}\right]$ & Configuration & & & \\
\hline$[5: 4]$ & $H$ : Majority irrigated & 24 & 3.833 & \multirow{2}{*}{$\begin{array}{c}3.690 \\
(0.021)\end{array}$} \\
\hline$[5: 4]$ & $H$ : Majority non-irrigated & 7 & 0.143 & \\
\hline$[4: 5]$ & $L:$ Majority irrigated & 12 & -3.167 & \multirow{2}{*}{$\begin{array}{c}3.167 \\
(0.170)\end{array}$} \\
\hline$[4: 5]$ & $L:$ Majority non-irrigated & 5 & 0.000 & \\
\hline
\end{tabular}

Note: $p$-value from $t$-test for the null of mean differences equal to 1 in parenthesis.

large, the unstructured and structured bargaining took about 10 minutes, and roughly the last 20 minutes were devoted to the post-experimental survey and the payment. The remaining 30 minutes were devoted to explaining the instructions to make sure that participants understood the game rules. Johnston et al. (2017) remark, for instruments in environmental valuation, the importance of a balance between the information required to elicit preferences via decision-making and the task complexity. In our game, information refers to the bargaining game rules. We argue that using maps, tokens, dice, and wooden logs makes these rules more tractable, reducing the associated complexity.

\section{Empirical Results}

In this section, we explore how transfers adjust to changes in the allocation of nonirrigated tiles. We argue that these adjustments can be interpreted as players' valuation of in-plot irrigation water. We present our analysis for the sample of egalitarian land allocation in a more intuitive manner, followed by the econometric analysis with the whole sample.

\subsection{Non-parametric results}

The left panel in Figure 3 presents the distribution of transfers from Player $H$ to Player $L$ for the Majority irrigated and Majority non-irrigated configurations when $\ell_{H}=5$. In the Majority irrigated all token transfers but one are positive, with an average value of 3.83 (see Table 2). By contrast, in the Majority non-irrigated the mean transfer is 0.143 , and the median is 0 . If players only consider the water conveyance cost for non-irrigated tiles, the average transfer in the Majority irrigated should be only 1 unit larger than in the Majority non-irrigated configuration. It corresponds to the induced cost of 1 , from keeping two rather than three irrigated plots. However, this difference is, on average, 3.69, more than three times the induced irrigation cost of a tile.

Similarly, the right panel in Figure 3 displays the distribution of transfers from Player $H$ to Player $L$ for the land configurations when $\ell_{H}=4$. We will use the labels Majority irrigated and Majority non-irrigated in the same manner, as these describe land configurations regardless of the identity of the player holding more tiles. When Player $L$ keeps five tiles, the mean transfer for the Majority irrigated is -3.17 (see Table 2), whereas the mean transfer for the Majority non-irrigated is zero. Although the difference in mean transfers between the two land configurations is 3.17 tokens, our smaller number of observations is insufficient to reject the null hypothesis that this difference is statistically equal to 1. 
Figure 3: Distribution of transfers with [5:4] (left panel) and [4:5] (right panel) land allocations. The land configurations Majority irrigated are displayed in blue, and Majority non-irrigated are displayed in orange.
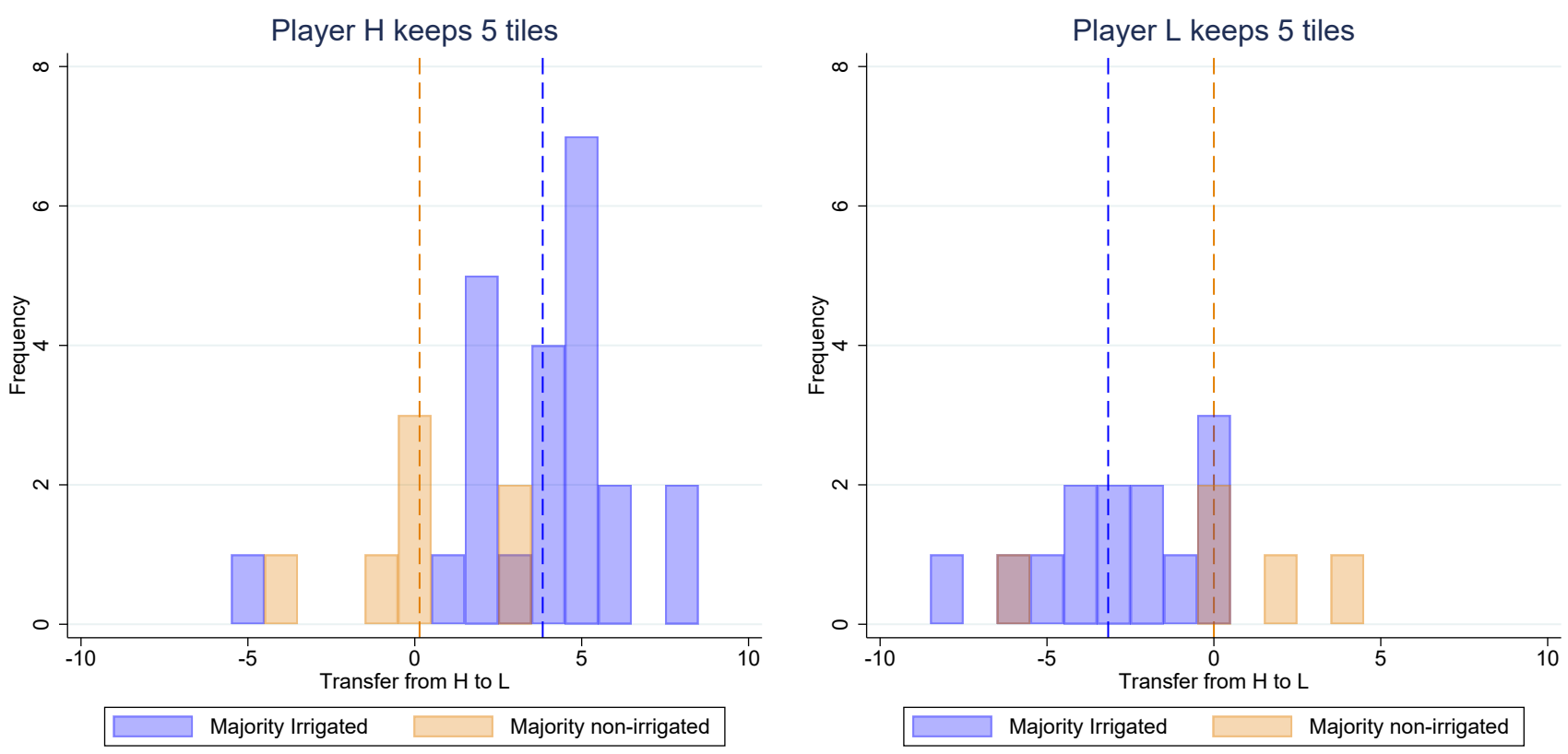

Note: In the Majority irrigated configuration, the player keeping 5 tiles holds 3 irrigated plus 2 non-irrigated tiles. In the Majority non-irrigated configuration, the player keeping 5 tiles holds 2 irrigated plus 3 nonirrigated tiles. Negative values in the horizontal axis represent a transfer from Player $L$ to Player $H$. Dashed vertical lines correspond to the average transfer for the allocation of the corresponding color.

Our results so far suggest that players are willing to pay for the attribute of in-plot irrigation more than three times the actual irrigation cost in the game. Below, we explore this pattern further with a regression analysis. The regression approach offers three additional insights. First, we can control for observed and unobserved heterogeneity. The former, by adding individual controls. The latter, by adding municipality fixed effects. Second, we can explore water valuation for the sample of egalitarian land allocation (i.e., one player keeps five tiles), as well as for the entire sample. Third, we can explore heterogeneities in water valuation by including interaction terms in our variables of interest.

\subsection{Regression analysis}

We estimate the following baseline equation

$$
T_{i}=\alpha_{0}+\alpha_{1} \ell_{H, i}^{I}+\alpha_{2} \ell_{H, i}+\boldsymbol{X}_{\boldsymbol{i}} \boldsymbol{\beta}+\epsilon_{i},
$$

where $T_{i}$ represents the token transfer from Player $H$ to Player $L$ of bargaining pair $i, \ell_{H, i}$ represents the total number of land plots accrued by Player $H, \ell_{H, i}^{I}$ the number of non-irrigated tiles accrued by this player, and $\epsilon_{i}$ is a random error. Here, $\boldsymbol{X}_{\boldsymbol{i}}$ is a vector of control variables. It includes, for each participant, its gender, age, marital status, and an 
indicator for land tenure (or possession). We also include municipality indicators and an indicator for the treatment of high yield variance as control variables.

The coefficient $\alpha_{1}$ in Equation 10 provides a measure of players' valuation of irrigated plots, as it represents the average number of tokens that Player $H$ transfers to Player $L$ for one additional irrigated tile. As in CV, our estimation identifies a relative valuation Carson and Hanemann, 2005). Following a reallocation of the costly attribute, its induced cost serves as a reference point for adjusting the token transfer.

Note that, since the variable $\ell_{H}$ is also included in the regression, the coefficient $\alpha_{1}$ captures the effect of changing one irrigated tile for one non-irrigated tile, keeping constant the total number of land plots accrued by player $H$. In other words, $\alpha_{1}$ is directly capturing the additional transfer (per tile) for the irrigation attribute. Recall that the value induced in the game for this attribute is one token. Hence, we explore whether there is evidence of overvaluation (resp. undervaluation) of irrigation water by testing if $\alpha_{1}$ is equal to 1 , against the alternative hypothesis that $\alpha_{1}$ is greater (resp. lower) than 1.

We perform two additional econometric exercises to study potential heterogeneities in our results. We thus include a variable $z_{i}$, representing a measure of water availability in the municipality in the first exercise, and the frequency of water mentions during the unstructured bargaining in the second exercise. The specification we estimate is

$$
T_{i}=\alpha_{0}+\alpha_{1} \ell_{H, i}^{I}+\alpha_{2} \ell_{H, i}+\alpha_{3}^{z} \ell_{H, i}^{I} \times z_{i}+\boldsymbol{X}_{\boldsymbol{i}} \boldsymbol{\beta}+\epsilon_{i}
$$

Here, we are interested in the coefficient $\alpha_{3}^{z}$ of the interaction term. In the first exercise, this coefficient provides information on the external validity of our results. It allows us to assess whether players' choices in the game respond to external factors that determine the value of water in their context (e.g., due to scarcity). In the second exercise, this coefficient provides information on internal validity. It captures the correlation between the transferred amount associated with irrigated tiles and the salience of water during the bargaining interactions.

Table 3 reports the regression results. In Panel A, we display the coefficients for the subsample of egalitarian land allocations; and in Panel B, the coefficients for the full sample. In both panels, columns 1 to 3 correspond to the specification in Equation 10 , and columns 4 and 5 to the specifications derived from Equation 11 .

Let us start with Panel A. In this case, Player $H$ accrues either 4 or 5 tiles, and only 2 or 3 of them can be irrigated. Hence, we re-scale the independent variables $\ell_{H}$ and $\ell_{H}^{I}$ to take the values of 0 and 1 . This facilitates the interpretation of the constant term in the estimation. Column 1 shows that when Player $H$ keeps the fifth tile, regardless of the irrigation attribute, she transfers on average 3 tokens to her counterpart (5.24-2.24). The constant term of -2.24 indicates that Player $H$ receives, on average, a transfer of 2.24 as compensation for accruing only 4 tiles.

In column 2, we include the dummy variable indicating whether Player $H$ is in the Majority irrigated land configuration. This allows us to disentangle how much of the observed average compensation is explained by differences in the allocation of irrigated tiles. The results suggest that, conditional on the total number of land plots kept by Player $H$, she transfers on average 3.48 additional tokens for an additional irrigated tile. This coefficient is robust to introducing individual controls and municipality fixed effects, suggesting that 
individual characteristics and unobservable municipality heterogeneity are not likely to be driving our results (column 3). We report at the bottom of Panel A the $p$-values for tests on whether the coefficient on the variable $\ell_{H, i}^{I}$ is equal to 1 . The observed rejection of this hypothesis in columns 2 and 3 confirms that the irrigation attribute is overvalued in our game.

We now focus on Panel B, reporting the full sample. We include the 16 observations in which the outcome of the bargaining game was less egalitarian (i.e., one player keeps at least six tiles) 8 With this estimation, we check whether our results are robust to a broader set of bargaining outcomes and are not driven by the selected sample of players choosing egalitarian allocations.

Column 1 shows that, before we consider the distribution of irrigated plots, an additional land tile that Player $H$ accrues increases the transfer by one token, on average. Interestingly, this coefficient decreases in magnitude and loses its statistical significance once we include in the estimation the number of irrigated tiles $\ell_{H}^{I}$ (column 2). The coefficient estimate on $\alpha_{1}$ indicates that, conditional on the total number of land plots of Player $H$, she transfers on average 2 tokens in exchange for a unit of irrigation. As before, this coefficient is robust to the inclusion of individual controls and municipality indicators. However, due to large standard errors in our estimation, we are not able to reject the null hypothesis of $\alpha_{1}=1$.

\section{Heterogeneity in water overvaluation}

In Column 4 of Table 3, we explore the potential heterogeneity of our results across different conditions of water availability in the municipality of each bargaining pair. We do this by estimating Equation 11, with an interaction between Player $H$ 's irrigated plots and an indicator variable for water supply. This variable takes the value of one if the water supply in the municipality of the bargaining pair $i$ is above the sample median and zero otherwise 9

The results differ across panels. Panel A reveals that the valuation of in-plot irrigation water does not differ across municipalities with low and high water supply in the egalitarian sample. Nevertheless, with the whole sample of bargaining pairs, in Panel B, we find evidence of heterogeneity in water valuation. In particular, in municipalities with a relatively low supply, players are willing to pay 3.23 additional tokens for an irrigated plot. This coefficient is statistically different from 1. By contrast, in municipalities with a relatively high supply, players pay on average 0.42 (resulting from 3.23-2.81) tokens for an irrigated plot. In this case, we cannot reject the hypothesis of equality to 1 . We interpret this result as evidence in favor of the external validity of our results: when taking into account the whole sample, the overvaluation of in-plot irrigation water comes from bargaining pairs in municipalities with a relatively lower supply in periods of water scarcity.

We now use the information from the oral bargaining recordings. In particular, we explore whether players' mentions of the word "water" when discussing possible land allocations have explanatory power on the observed overvaluation. Figure A.1 (see the Appendix) shows that there are large differences in the frequency of water mentions across treatment variations. When players are allowed to split the land, there was at least one mention of water among

\footnotetext{
${ }^{8}$ In all 64 bargaining outcomes, the disagreement payoff was never implemented.

${ }^{9}$ Note that our municipality indicators absorb the direct effect of this variable on token transfers.
} 
Table 3: OLS Estimations: Token Transfers for [5:4] and [4:5] land allocations (Panel A) and for the entire sample (Panel B).

\begin{tabular}{|c|c|c|c|c|c|}
\hline & $(1)$ & $(2)$ & $(3)$ & $(4)$ & $(5)$ \\
\hline \multicolumn{6}{|l|}{ Panel A: [5:4] and [4:5] Allocations } \\
\hline$\ell_{H}$ & $\begin{array}{c}5.24^{* * *} \\
(0.92)\end{array}$ & $\begin{array}{c}3.56^{* * *} \\
(0.98)\end{array}$ & $\begin{array}{c}3.31^{* *} \\
(1.47)\end{array}$ & $\begin{array}{l}3.33^{* *} \\
(1.52)\end{array}$ & $\begin{array}{c}3.28^{* *} \\
(1.60)\end{array}$ \\
\hline$\ell_{H}^{I}$ & & $\begin{array}{c}3.48^{* * *} \\
(0.91)\end{array}$ & $\begin{array}{c}3.37^{* * *} \\
(1.07)\end{array}$ & $\begin{array}{c}3.31^{* *} \\
(1.30)\end{array}$ & $\begin{array}{c}3.67^{* *} \\
(1.42)\end{array}$ \\
\hline$\ell_{H}^{I} \times$ High Supply & & & & $\begin{array}{c}0.25 \\
(2.58)\end{array}$ & \\
\hline$\ell_{H}^{I} \times$ Water Mentions & & & & & $\begin{array}{l}-0.03 \\
(0.14)\end{array}$ \\
\hline Constant & $\begin{array}{c}-2.24^{* * *} \\
(0.75)\end{array}$ & $\begin{array}{c}-3.26^{* * *} \\
(0.65)\end{array}$ & $\begin{array}{l}-3.62 \\
(2.16)\end{array}$ & $\begin{array}{l}-3.70 \\
(2.41)\end{array}$ & $\begin{array}{l}-3.79 \\
(2.35)\end{array}$ \\
\hline Observations & 48 & 48 & 48 & 48 & 47 \\
\hline $\begin{array}{l}\text { (1) } p \text {-val. coeff. } \ell_{H}^{I}=1 \\
\text { (2) Coeff. } \ell_{H}^{I}+\ell_{H}^{I} \times \text { High Supply } \\
\text { (3) Coeff. } \ell_{H}^{I}+\ell_{H}^{I} \times 50^{t h} \text { Water Mentions } \\
\text { (4) Coeff. } \ell_{H}^{I}+\ell_{H}^{I} \times 90^{t h} \text { Water Mentions }\end{array}$ & & 0.01 & 0.03 & $\begin{array}{c}0.09 \\
3.55(0.25)\end{array}$ & $\begin{array}{l}3.57(0.05) \\
3.11(0.30)\end{array}$ \\
\hline \multicolumn{6}{|l|}{ Panel B: All Allocations } \\
\hline$\ell_{H}$ & $\begin{array}{c}1.00^{* * *} \\
(0.28)\end{array}$ & $\begin{array}{l}-0.13 \\
(0.65)\end{array}$ & $\begin{array}{l}-0.03 \\
(0.68)\end{array}$ & $\begin{array}{c}0.82 \\
(0.81)\end{array}$ & $\begin{array}{c}0.18 \\
(0.69)\end{array}$ \\
\hline$\ell_{H}^{I}$ & & $\begin{array}{l}2.06^{*} \\
(1.08)\end{array}$ & $\begin{array}{c}2.18^{* *} \\
(1.06)\end{array}$ & $\begin{array}{c}3.23^{* * *} \\
(1.16)\end{array}$ & $\begin{array}{c}0.96 \\
(1.28)\end{array}$ \\
\hline$\ell_{H}^{I} \times$ High Supply & & & & $\begin{array}{c}-2.81^{*} \\
(1.61)\end{array}$ & \\
\hline$\ell_{H}^{I} \times$ Water Mentions & & & & & $\begin{array}{c}0.22^{* * *} \\
(0.08)\end{array}$ \\
\hline Constant & $\begin{array}{c}-3.47^{* *} \\
(1.42)\end{array}$ & $\begin{array}{c}-3.54^{* *} \\
(1.44)\end{array}$ & $\begin{array}{l}-3.40 \\
(2.70)\end{array}$ & $\begin{array}{l}-3.26 \\
(2.49)\end{array}$ & $\begin{array}{l}-1.27 \\
(2.75)\end{array}$ \\
\hline Observations & 64 & 64 & 64 & 64 & 63 \\
\hline $\begin{array}{l}\text { (1) } p \text {-val. coeff. } \ell_{H}^{I}=1 \\
\text { (2) Coeff } \ell_{H}^{I}+\ell_{H}^{I} \times \text { High Supply } \\
\text { (3) Coeff. } \ell_{H}^{I}+\ell_{H}^{I} \times 50^{t h} \text { Water Mentions } \\
\text { (4) Coeff. } \ell_{H}^{I}+\ell_{H}^{I} \times 90^{t h} \text { Water Mentions }\end{array}$ & & 0.33 & 0.27 & $\begin{array}{c}0.06 \\
0.42(0.71)\end{array}$ & $\begin{array}{c}1.62(0.60) \\
4.70(<0.001)\end{array}$ \\
\hline Controls & No & No & Yes & Yes & Yes \\
\hline \multicolumn{6}{|c|}{$\begin{array}{l}\text { Note: Huber-White standard errors in parentheses. }{ }^{* * *} \mathrm{p}<0.01,{ }^{* *} \mathrm{p}<0.05,{ }^{*} \mathrm{p}<0.1 . \ell_{H, i} \text { and } \ell_{H, i}^{I} \text { in } \\
\text { panel A are scaled to take values of } 0 \text { and } 1 \text {. Control variables for each player include: gender, age, marital } \\
\text { status, a dummy variable for whether player has a farm, and municipality indicator variables. Row (1), at } \\
\text { the bottom of each panel, presents the p-value of a test with } H_{o}: \alpha_{1}=1 \text {. Row }(2) \text { presents the sum of the } \\
\text { coefficient estimate on the } \ell_{H, i}^{I} \text { and the interaction with High Water Supply and the } p \text {-value of a test on } \\
\text { whether this sum equals } 1 \text {. Rows (3) and (4) present the marginal effect of irrigated land plots evaluated at } \\
\left.\text { the median and the } 90^{t h} \text { percentile of the number of water mentions ( } 3 \text { and } 17\right) \text {, respectively, and the } p \text {-value } \\
\text { of a test on whether this marginal effect equals } 1 \text {. }\end{array}$} \\
\hline
\end{tabular}


roughly sixty percent of the bargaining pairs, and water was mentioned on average 5.7 times in each bargaining pair. By contrast, when players were not allowed to divide the land, water mentions occurred on thirty percent of the bargaining interactions, with an average of 0.7 times per pair. Wilcoxon rank-sum tests for the between-treatment comparisons yield a $p$-value $<0.001$.

The differences that we observe in water mentions across treatments suggest that players, in fact, bargain over water, when alternative land configurations are allowed. In this case, Player $H$ mentions water on average 3.1 times during the bargaining. This value is slightly larger than the average for Player $L$ (2.6 times), although this difference is not statistically significant (see Figure A.2). Overall, there is a strong positive correlation (0.6) between the number of times that Players $H$ and $L$ mention water within bargaining pairs.

Moving to the regression results, column 5 of Table 3 displays the results when we add the frequency of water mentions in the explicit bargaining stage. As occurred with our measure of water supply by municipality, we only find evidence of potential heterogeneity in water valuation with the whole sample of bargaining pairs. In Panel $\mathrm{B}$, the coefficient capturing the interaction of interest is positive. Its magnitude indicates that at the median number of water mentions (3), Player $H$ transfers on average 1.62 tokens to Player $L$. By contrast, for bargaining pairs in the $90^{t h}$ percentile of water mentions (17), the irrigation attribute induces an average transfer of 4.70. This effect is statistically different from 1.

A conjecture for the lack of evidence about heterogeneous effects in the sample of egalitarian land allocations is how the bargaining process develops. It is possible that in very disputed bargaining processes (i.e., with participants having similar bargaining skills or with an ex-ante goal of accruing at least 4 tiles), the additional valuation of water is implicit in the offered transfer. When bargaining abilities are less symmetric, or alternatively, when players can foresee the distribution of larger expected profits despite the higher land inequality, water valuation becomes an explicit argument affecting the transfers.

\section{Conclusions}

The purpose of valuation is to provide helpful information for the welfare analysis of nonmarket goods (Carlsson, 2010). Contingent valuation (CV) works well for goods and services with a low degree of rivalry (Johnston et al., 2017). However, if significant advances in environmental valuation require focusing on choice behavior-not only on value-(Adamowicz, 2004), and if collaboration is an essential part of the future of environmental policy (Shogren and Taylor, 2008), bargaining experiments might result informative in scenarios in which property rights are ex-ante undefined.

We characterize a bargaining game that will be of use for such scenarios. In our game, (i) the good must be divisible into units, (ii) some of the units must have an attribute associated with a cost, and (iii) players have an endowment of tradable units that can be transferred in exchange for accruing a larger share of the good. We show that, since the transfer and the attribute's cost enter the payoffs function linearly, the different configurations for the division of the good yield transfers that differ only in the attribute's cost. This

is true in a cooperative and in a non-cooperative bargaining framework, and also holds as a best-response function out of equilibrium. When the differences between the mean transfers 
across configurations do not match the attribute's cost, we argue that this deviation from the "induced cost" reveals an over(under) valuation of the framed attribute.

We show an application for the case of water valuation with Colombian farmers. In a land division game, two alternative configurations of the land allocation differ in the number of irrigated tiles each participant has. Since each player accrues either two or three irrigated tiles, and the irrigation cost was 1 , the difference in the mean transfers between the two configurations should be one token, exactly this irrigation cost. In the experiment, we find that this difference was of at least three tokens, indicating an overvaluation of water with respect to its induced cost. Besides, we find that this overvaluation might be driven by municipalities with a water supply below the median.

We close this paper by discussing some elements to consider in the design of future bargaining experiments with valuation purposes. First, we argue that bargaining games can be regarded as a complement, not a substitute for standard valuation techniques. For instance, since pretesting is strongly encouraged before the full deployment of a contingent valuation instrument (Johnston et al., 2017), one could use bargaining experiments with real incentives in smaller populations as an additional validity check. It would serve to test whether the targeted population values the environmental good or service of interest. Consider the methodological issues for valuing water in developing countries due to lack of trust. Participants might be less willing to under-report their valuation in a bargaining game involving monetary incentives, especially when its framing does not evoke governmental authorities but rather peer interactions.

Second, the calibration of induced costs is fundamental. The efforts to connect the relative overvaluation in the game to any conclusion reflecting an absolute valuation of this attribute must be made carefully. A good calibration would ease the connection between bargaining games and standard welfare analysis by assigning random prices for this attribute. In the same manner that CV grants incentive compatibility by presenting a single binary choice to each respondent, the value of the costly attribute can be arbitrarily assigned (from a range of values of interest) to each bargaining pair. However, we leave the analysis of the aggregation properties of the costly attribute's empirical valuations for future research.

Third, it is paramount to acknowledge the trade-off between framing and complexity. In the same vein that Johnston et al. (2017) raise this issue for the design of CV instruments, bargaining games need to be sufficiently simple to guarantee that the purpose of the game is clear to the respondents, but also enough informative to make sure that participants connect elements of their identity with the costly attribute (Cárdenas and Ostrom, 2004). Whereas the game from Section 1 gives more weight to the former criterion, we acknowledge that our application to water valuation gave more weight to the latter. Even if the explanation of the irrigation costs devoted some additional time, our results, particularly those connecting water mentions and transfers, would suggest success in connecting the experiment's framing with the relevance that irrigation water has outside the game.

\section{References}

Abramson, A., Becker, N., Garb, Y., and Lazarovitch, N. (2011). Willingness to pay, borrow, and work for rural water service improvements in developing countries. Water Resources 
Research, 47(11).

Adamowicz, W. L. (2004). What's it worth? an examination of historical trends and future directions in environmental valuation. Australian Journal of Agricultural and Resource Economics, 48(3):419-443.

Ahlheim, M. and Lehr, U. (2008). Equity and Aggregation in Environmental Valuation. Diskussionspapiere aus dem Institut für Volkswirtschaftslehre der Universität Hohenheim 295/2008, Department of Economics, University of Hohenheim, Germany.

Andersen, S., Harrison, G. W., Lau, M. I., and Rutström, E. E. (2008). Eliciting risk and time preferences. Econometrica: Journal of the Econometric Society, 76(3):583-618.

Andreoni, J. and Sprenger, C. (2012). Estimating time preferences from convex budgets. American Economic Review, 102(7):3333-56.

Banerji, A., Meenakshi, J., and Khanna, G. (2012). Social contracts, markets and efficiency: Groundwater irrigation in North India. Journal of Development Economics, 98(2):228-237.

Barrio, M. and Loureiro, M. L. (2010). A meta-analysis of contingent valuation forest studies. Ecological Economics, 69(5):1023-1030.

Boxall, P. C., Adamowicz, W. L., Swait, J., Williams, M., and Louviere, J. (1996). A comparison of stated preference methods for environmental valuation. Ecological Economics, 18(3):243-253.

Brown, T. C. and Gregory, R. (1999). Why the WTA-WTP disparity matters. Ecological Economics, 28(3):323-335.

Bulte, E., Gerking, S., List, J. A., and De Zeeuw, A. (2005). The effect of varying the causes of environmental problems on stated wtp values: evidence from a field study. Journal of Environmental Economics and Management, 49(2):330-342.

Cárdenas, J.-C. and Ostrom, E. (2004). What do people bring into the game? experiments in the field about cooperation in the commons. Agricultural Systems, 82(3):307-326.

Carlsson, F. (2010). Design of stated preference surveys: Is there more to learn from behavioral economics? Environmental and Resource Economics, 46(2):167-177.

Carson, R. T. (2012). Contingent valuation: A practical alternative when prices aren't available. Journal of Economic Perspectives, 26(4):27-42.

Carson, R. T., Flores, N. E., and Meade, N. F. (2001). Contingent valuation: controversies and evidence. Environmental and Resource Economics, 19(2):173-210.

Carson, R. T. and Hanemann, W. M. (2005). Contingent valuation. Handbook of Environmental Economics, 2:821-936. 
Cummings, R. G. and Taylor, L. O. (1999). Unbiased value estimates for environmental goods: a cheap talk design for the contingent valuation method. American Economic

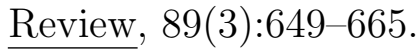

De Groot, R., Brander, L., Van Der Ploeg, S., Costanza, R., Bernard, F., Braat, L., Christie, M., Crossman, N., Ghermandi, A., Hein, L., et al. (2012). Global estimates of the value of ecosystems and their services in monetary units. Ecosystem Services, 1(1):50-61.

Devoto, F., Duflo, E., Dupas, P., Parienté, W., and Pons, V. (2012). Happiness on tap: piped water adoption in urban Morocco. American Economic Journal: Economic Policy, $4(4): 68-99$.

Diamond, P. A. and Hausman, J. A. (1994). Contingent valuation: is some number better than no number? Journal of Economic Perspectives, 8(4):45-64.

Duflo, E. and Pande, R. (2007). Dams. The Quarterly Journal of Economics, 122(2):601-646.

Foster, A. and Sekhri, S. (2008). Can expansion of markets for groundwater decelerate the depletion of groundwater resource in rural India? Manuscript submitted for publication.

Gáfaro, M. and Mantilla, C. (2020). Land division: A lab-in-the-field bargaining experiment. Journal of Development Economics, page 102525.

Greenland-Smith, S., Brazner, J., and Sherren, K. (2016). Farmer perceptions of wetlands and waterbodies: Using social metrics as an alternative to ecosystem service valuation. Ecological Economics, 126:58-69.

Gurven, M., Zanolini, A., and Schniter, E. (2008). Culture sometimes matters: Intra-cultural variation in pro-social behavior among Tsimane Amerindians. Journal of Economic Behavior \& Organization, 67(3-4):587-607.

Harrison, G. W. (2006). Experimental evidence on alternative environmental valuation methods. Environmental and Resource Economics, 34(1):125-162.

Hausman, J. (2012). Contingent valuation: from dubious to hopeless. Journal of Economic Perspectives, 26(4):43-56.

Henrich, J., Boyd, R., Bowles, S., Camerer, C., Fehr, E., Gintis, H., McElreath, R., et al. (2001). Cooperation, reciprocity and punishment in fifteen small-scale societies. American Economic Review, 91(2):73-78.

Henrich, J. P., Boyd, R., Bowles, S., Fehr, E., Camerer, C., Gintis, H., et al. (2004). Foundations of human sociality: Economic experiments and ethnographic evidence from fifteen small-scale societies. Oxford University Press on Demand.

Holt, C. A. and Laury, S. K. (2002). Risk aversion and incentive effects. American Economic Review, 92(5):1644-1655.

Jack, B. K. (2009). Upstream-downstream transactions and watershed externalities: Experimental evidence from Kenya. Ecological Economics, 68(6):1813-1824. 
Jacoby, H. G., Murgai, R., and Ur Rehman, S. (2004). Monopoly power and distribution in fragmented markets: The case of groundwater. The Review of Economic Studies, 71(3):783-808.

Janssen, M. A., Bousquet, F., Cardenas, J.-C., Castillo, D., and Worrapimphong, K. (2012). Field experiments on irrigation dilemmas. Agricultural Systems, 109:65-75.

Johnston, R. J., Boyle, K. J., Adamowicz, W., Bennett, J., Brouwer, R., Cameron, T. A., Hanemann, W. M., Hanley, N., Ryan, M., Scarpa, R., et al. (2017). Contemporary guidance for stated preference studies. Journal of the Association of Environmental and Resource Economists, 4(2):319-405.

Jorgensen, B. S., Syme, G. J., Bishop, B. J., and Nancarrow, B. E. (1999). Protest responses in contingent valuation. Environmental and Resource Economics, 14(1):131-150.

Kahneman, D., Knetsch, J. L., and Thaler, R. H. (1990). Experimental tests of the endowment effect and the Coase theorem. Journal of Political Economy, 98(6):1325-1348.

Kim, Y., Kling, C. L., and Zhao, J. (2015). Understanding behavioral explanations of the WTP-WTA divergence through a neoclassical lens: Implications for environmental policy. Annual Review of Resource Economics, 7:169.

Knetsch, J. L. (1989). The endowment effect and evidence of nonreversible indifference curves. American Economic Review, 79(5):1277-1284.

Knetsch, J. L. (2007). Biased valuations, damage assessments, and policy choices: The choice of measure matters. Ecological Economics, 63(4):684-689.

Kumar, M. D., Malla, A. K., and Tripathy, S. K. (2008). Economic value of water in agriculture: Comparative analysis of a water-scarce and a water-rich region in India. Water International, 33(2):214-230.

Loomis, J. B. (2000). Environmental valuation techniques in water resource decision making. Journal of Water Resources Planning and Management, 126(6):339-344.

Meyerhoff, J. and Liebe, U. (2006). Protest beliefs in contingent valuation: explaining their motivation. Ecological Economics, 57(4):583-594.

Moreno-Sanchez, R., Maldonado, J. H., Wunder, S., and Borda-Almanza, C. (2012). Heterogeneous users and willingness to pay in an ongoing payment for watershed protection initiative in the Colombian Andes. Ecological Economics, 75:126-134.

Nauges, C. and Whittington, D. (2010). Estimation of water demand in developing countries: An overview. The World Bank Research Observer, 25(2):263-294.

Perfetti, J. J., Delgado, M., Blanco, J., Paredes, G., García, A., Naranjo, J., Pantoja, J., González, L., et al. (2019). Adecuación de tierras y el desarrollo de la agricultura colombiana: políticas e instituciones. Technical report, Fedesarrollo. 
Plott, C. R. and Zeiler, K. (2005). The willingness to pay-willingness to accept gap, the "endowment effect," subject misconceptions, and experimental procedures for eliciting valuations. American Economic Review, 95(3):530-545.

Roth, A. E. and Malouf, M. (1979). Information in bargaining. Psychological Review, 86(6):574-594.

Rubinstein, A. (1982). Perfect equilibrium in a bargaining model. Econometrica: Journal of the Econometric Society, pages 97-109.

Schläpfer, F. (2006). Survey protocol and income effects in the contingent valuation of public goods: A meta-analysis. Ecological Economics, 57(3):415-429.

Sekhri, S. (2014). Wells, water, and welfare: the impact of access to groundwater on rural poverty and conflict. American Economic Journal: Applied Economics, 6(3):76-102.

Shogren, J. F. (2005). Experimental methods and valuation. Handbook of Environmental Economics, 2:969-1027.

Shogren, J. F. and Taylor, L. O. (2008). On behavioral-environmental economics. Review of Environmental Economics and Policy, 2(1):26-44.

Smith, V. K. and Osborne, L. L. (1996). Do contingent valuation estimates pass a "scope" test? a meta-analysis. Journal of Environmental Economics and Management, 31(3):287301.

Tunçel, T. and Hammitt, J. K. (2014). A new meta-analysis on the WTP/WTA disparity. Journal of Environmental Economics and Management, 68(1):175-187.

Vatn, A. (2004). Environmental valuation and rationality. Land Economics, 80(1):1-18.

Weldesilassie, A. B., Frör, O., Boelee, E., and Dabbert, S. (2009). The economic value of improved wastewater irrigation: A contingent valuation study in Addis Ababa, Ethiopia. Journal of Agricultural and Resource Economics, pages 428-449.

Whittington, D. (2002). Improving the performance of contingent valuation studies in developing countries. Environmental and Resource Economics, 22(1-2):323-367.

Whittington, D. (2010). What have we learned from 20 years of stated preference research in less-developed countries? Annu. Rev. Resour. Econ., 2(1):209-236.

Whittington, D. and Pagiola, S. (2012). Using contingent valuation in the design of payments for environmental services mechanisms: a review and assessment. The World Bank Research Observer, 27(2):261-287. 


\section{A Appendix}

\section{A.1 Proof of proposition 1}

Form the first order condition of the maximization problem in Equation 6 we have:

$$
\begin{aligned}
\frac{\partial G}{\partial W_{1}} \frac{\partial W_{1}}{\partial T}+\frac{\partial G}{\partial W_{2}} \frac{\partial W_{2}}{\partial T} & =0 \\
-\frac{\partial G}{\partial W_{1}}+\frac{\partial G}{\partial W_{2}} & =0
\end{aligned}
$$

Let $S=-\frac{\partial G}{\partial W_{1}}+\frac{\partial G}{\partial W_{2}}$, applying the Implicit Function Theorem,

$$
\begin{aligned}
\frac{\partial T}{\partial y_{1}} & =-\frac{\frac{\partial S}{\partial y_{1}}}{\frac{\partial S}{\partial T}} \\
& =-\frac{-\frac{\partial^{2} G}{\partial W_{1}^{2}} \frac{\partial W_{1}}{\partial y_{1}}-\frac{\partial^{2} G}{\partial W_{1} W_{2}} \frac{\partial W_{2}}{\partial y_{1}}+\frac{\partial^{2} G}{\partial W_{2}^{2}} \frac{\partial W_{2}}{\partial y_{1}}+\frac{\partial^{2} G}{\partial W_{1} W_{2}} \frac{\partial W_{1}}{\partial y_{1}}}{-\frac{\partial^{2} G}{\partial W_{1}^{2}} \frac{\partial W_{1}}{\partial T}-\frac{\partial^{2} G}{\partial W_{1} W_{2}} \frac{\partial W_{2}}{\partial T}+\frac{\partial^{2} G}{\partial W_{2}^{2}} \frac{\partial W_{2}}{\partial T}+\frac{\partial^{2} G}{\partial W_{1} W_{2}} \frac{\partial W_{1}}{\partial T}} \\
& =-F .
\end{aligned}
$$

\section{A.2 Additional Tables and Figures}

Table A.1: Main characteristics of municipalities in the sample

\begin{tabular}{lcccccc}
\hline & & Share & Main & Mean & \multicolumn{2}{c}{ Water Supply } \\
\cline { 6 - 7 } Municipality & Population & Rural & Crop & Rainfall & Dry Year & Humid Year \\
\hline California & 2020 & 45.64 & Potato & 822.27 & 46.88 & 34.69 \\
Confines & 2698 & 84.95 & Coffee & 2602.15 & 110.82 & 56.52 \\
El Playón & 11520 & 51.2 & Cocoa & 1817.91 & 583.49 & 431.78 \\
Matanza & 5201 & 79.12 & Coffee & 999.55 & 99.46 & 73.60 \\
Ocaña & 99741 & 9.14 & Tomato & 1032.82 & 227.15 & 124.93 \\
Rionegro & 26680 & 74.38 & African palm oil & 1832.38 & 1108.56 & 820.33 \\
Simacota & 7593 & 67.07 & African palm oil & 2264.21 & 1289.92 & 799.75 \\
Vélez & 18932 & 45.7 & Sugar cane (Panela) & 2086.48 & 784.38 & 400.04 \\
\hline
\end{tabular}

Note: Population and the share of rural population (\%) from CEDE municipality data. Mean rainfall measures the average of yearly rainfall between the 1950s until the 2020s in the closest IDEAM station in $\mathrm{mm}$, water supply from ENA-IDEAM by type of year as classified by in $10^{6}$ cubic meters. 
Figure A.1: Distribution of the frequency of 'water' mentions during the unstructured bargaining phase by treatment variations.

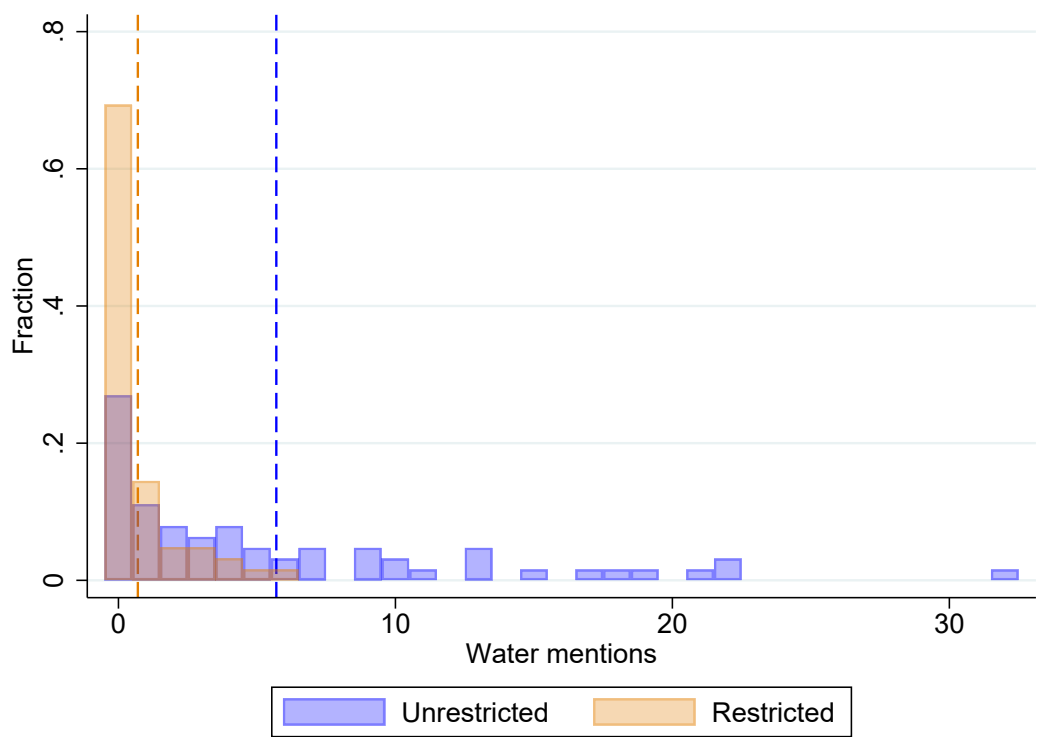

Note: The unconstrained treatment corresponds to the treatment variation in which players are allowed to split the land (our sample of study).

Figure A.2: Distribution of the number of times participants $H$ and $L$ said 'water' during the unstructured bargaining phase.

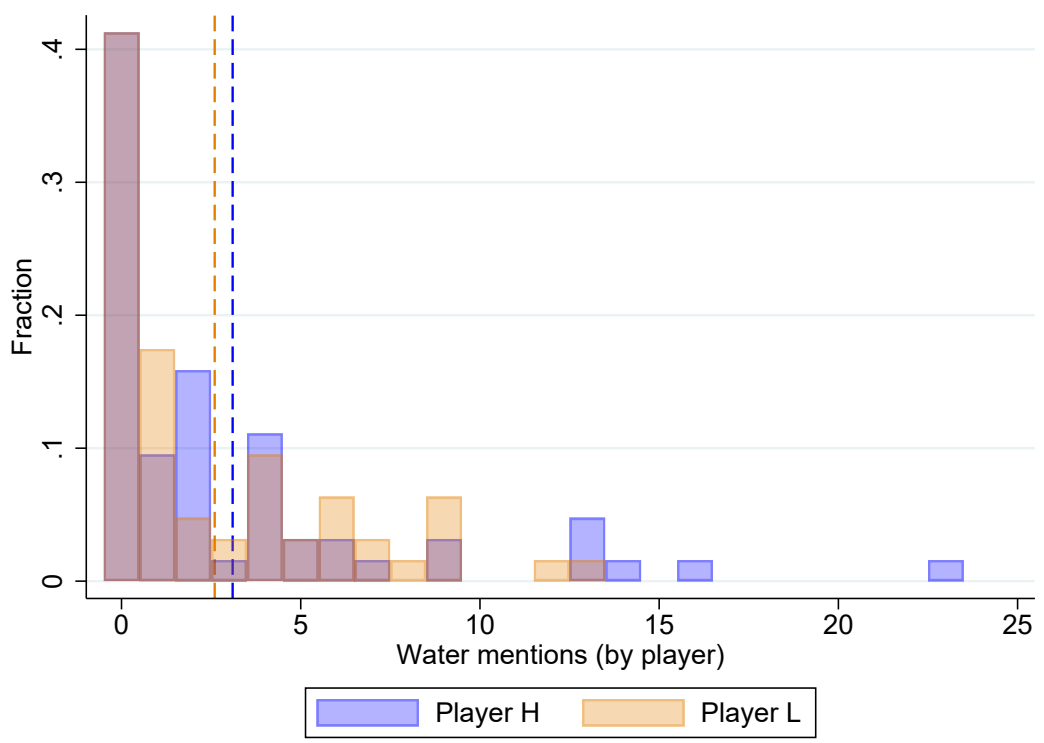

Note: Dashed vertical lines correspond to the average number of times Player $H$ (in blue) and Player $L$ (in orange) mentioned 'water' during the bargaining phase. 


\section{A.3 Experimental Protocol: Translated Version}

\section{General Instructions}

Welcome. We want to thank you for your participation in this activity, which will last for approximately one hour. It includes the explanation of the game (about 35 minutes), playing the game (10 minutes) and a short survey at the end (10 minutes). Once the survey is completed we will give you the earnings from the game. This activity has been funded by Universidad del Rosario.

This is a bargaining game in which you and the person with whom you are matched to play the game have jointly inherited a land plot that you will have to divide. Each one of you have also inherited some tokens that represent cash. You can use these tokens in case you want to keep a larger share of the plot. We will explain how are computed your earnings based on the number of tokens and the number of tiles from the land plot you keep at the end of the game.

It is important to clarify that earnings from this game do not correspond to a participation fee, so we expect that you participate in other research activities in the future, even if there will be no payment. We introduce earnings to make sure your game decisions have economic consequences, so they seem closer to your everyday decisions. The other participants in this activity will not know, during or after the experiment, anything about your earnings or about your responses in the survey. The game rules you are about to hear might be different from the rules that apply when other participants from this municipality took part in the game. Therefore, the comments you might have heard do not necessarily apply.

\section{Introduction: the Land Division}

This activity aims at understanding the production and division decisions of agricultural land in \{name of municipality\}. You have jointly inherited the plot "The Triangle," composed of nine smaller tiles of equal size. In addition, each one of you have inherited 10 tokens.

(The monitor delivers the triangular map and the tokens)

At the end of the game, for each tile you own you will receive a die. If you keep one tile, you receive one die; you keep two tiles, you receive two dice, and so on. All dice will be rolled simultaneously inside a box. The sum of all dice outcomes will be your total output, which will be exchanged for tokens. We will explain later other land production rules in this game.

Keeping more tiles means a higher production after rolling the dice, but you will need to agree with the other person how many tokens will be exchanged to accept the proposal. You are allowed to use all your tokens in the bargaining game. It is possible that one of you keep all nine tiles, or that you find an acceptable division of the plot.

Keeping all, or most, of the tiles is good because you will roll more dice, so you can produce more tokens. But you will have to bargain on how many of the 10 tokens you will give to the other person. 
At the end of the game you will receive $\$ 1.000$ (Colombian pesos) for every token you own. All the yellow (originally endowed) tokens and all the output tokens are taken into account to compute your earnings.

\section{Land Production}

The output of each tile in the land plot could be good, average, or poor. Since not every person is equally productive with land, one of you will roll big dice and the other one will roll small dice at the end of the game. With the big dice, the output per tile could be $[\mathbf{3}$, $\mathbf{4}$, or $\mathbf{5} / \mathbf{2}, \mathbf{4}$, or $\mathbf{6}]$ tokens. With the small dice, the output per tile could be $[\mathbf{2}, \mathbf{3}$, or 4 / 1, 3, or 5] tokens. Since each number appears twice in each die, the probability that the output of each tile is good, average, or poor is the same.

We will divide you into two groups of players. Each one of you will roll a plastic die. The two persons with the highest number will form and group, and the two persons with the lowest number will form the other group.

Now we will decide who will have the big and the small dice in each group. Each one will roll again the die, and the person in each group with the highest number will keep the big dice and the other will keep the small dice.

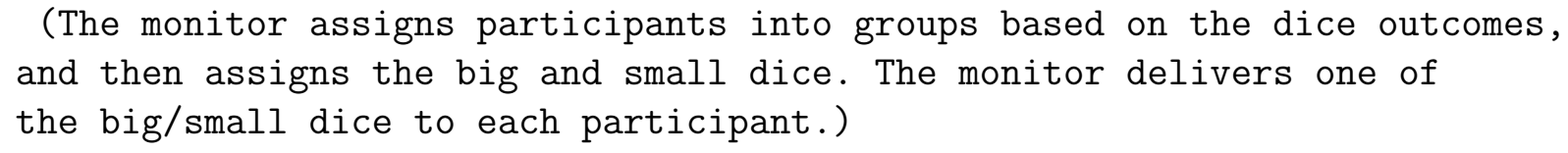

\section{Production Costs: Water}

Two out of the three triangles sides are marked with a blue line. This blue line represents the water stream that covers some of the tiles. A tile has access to water when one of the sides of the tile is covered by the blue line. If this is the case, a drop of water is drawn in the middle of the tile. In total, five tiles have access to water, and four tiles do not have access to water.

In the tiles with access to water the production cost is zero. In the tiles without access to water the production cost is one. When we compute your earnings, we will substract one token for each tile without access to water.

\section{Production Costs: Boundaries}

If you decide to divide the land plot you will need to set the boundaries that divide each person's tiles. When one of you makes a proposal on how to divide the land, we will put one of these red logs to draw the boundaries. Each red log drawing a boundary costs one token to each one of you. When we compute your earnings, we will substract one token for each red log.

(The monitor draws a division and puts in the map the corresponding red logs) 


\section{Computing Earnings}

You will receive $\$ 1.000$ (Colombian pesos) for every token you kept at the end of the game. Remember there are two strategies to accrue tokens. You can keep your own tokens and demand tokens from the other person in exchange for land tiles; or you can keep tiles and produce additional tokens by rolling the dice. Remember that you will have a deduction in your earnings for each tile without access to water, and for each red log drawing a boundary.

The following is a step-by-step summary of instructions:

1. Use the red logs to mark the proposed land division and decide how many tokens would be acceptable.

2. Verify the minimum and maximum production according to the proposed land division.

3. Subtract one token per tile without access to water, and one token per red log.

4. Sum the minimum and maximum output after costs and your remaining tokens.

5. Multiply by $\$ 1.000$ (Colombian pesos) the final number of tokens

\section{Example}

[See Figure A.3]

1. You have the big dice. You propose to keep 6 tiles in exchange for 3 tokens.

2. Your minimum output per tile is $[\mathbf{3} / \mathbf{2}]$ and your maximum output per tile is $[\mathbf{5} /$ 6] tokens. With your six tiles your minimum output is $[\mathbf{1 8} / \mathbf{1 2}]$ and your maximum output is $[\mathbf{3 0} / \mathbf{3 6}]$ tokens.

3. Your production cost is 5 tokens. Three tiles do not have access to water and you use two red logs to draw the boundaries.

4. Subtracting your costs and the 3 tokens you give to the other person, your minimum number of tokens will be $[\mathbf{1 0}+\mathbf{1 8 - 5 - 3}=\mathbf{2 0} / \mathbf{1 0}+\mathbf{1 2 - 5 - 3}=14]$ and your maximum number of tokens will be $[10+30-8=32 / 10+36-8=38]$.

5. Your earnings will be between $[\$ 20.000$ and $\$ 32.000 / \$ 14.000$ and $\$ 36.000]$ (Colombian pesos) if you reach this agreement.

\section{How to bargain?}

You will have 5 minutes to bargain. We will not be present during the bargaining phase, but the conversation will be recorded. This will help us to understand which are the key elements in the bargaining process. Please let us know if you reach an agreement before the time is over.

Any of you can make a proposal. The bargaining might include a transfer, that must be of at most the 10 endowed tokens. You can make an agreement in which the plot is divided, 


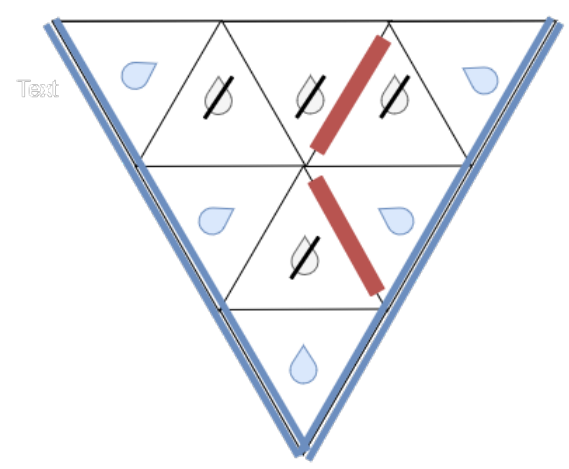

Figure A.3: Example with a [6:3] plot division.

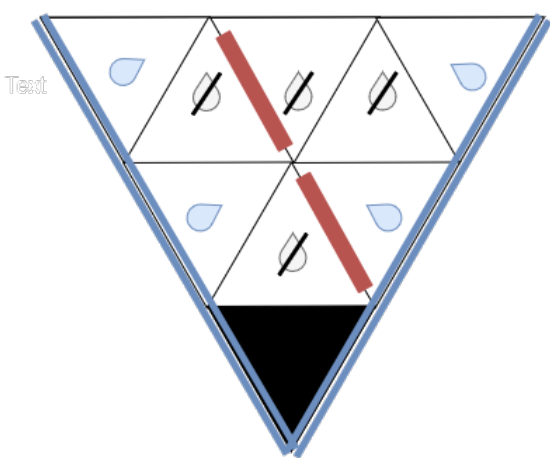

Figure A.4: Land division if an agreement is not reached.

or not, and you might use, or not, the endowed tokens. Once the time is over the player with the big die will make a proposal including the land division, and the proposed tokens to be demanded or given. We will record this proposal in the contract sheet. Then, the player with the small die will decide whether to accept or reject the proposal. In case of rejection, he/she could make a counterproposal including the land division, and the proposed tokens to be demanded or given. This is the last chance to reach an agreement.

\section{What happens when an agreement is not reached?}

Each person keeps the 10 endowed tokens and received two tiles with access to water, and two tiles without access to water as is shown in the map (see Figure A.4). Under this land division one of the tiles is lost due to the lawyers' fees to reach this arrangement.

\section{End of the Game}

In private, I will give you a die for each tile owned at the end of the game. You will roll all dice inside a box, and only the two of us will know the outcome. In other words, the other person will not know your dice roll outcome nor your final earnings. 
(The coordinator asks if there are questions.)

If there are no further questions we will read aloud the informed consent. This is a document in which you declare that you are here under your own will and that you have understood the rules of the game. And we declare that all the gathered information will be treated under confidentiality and only with academic purposes.

(The coordinator reads the informed consent.)

If you agree with the informed consent, please sign it.

\section{A.4 Experimental Protocol: Original Version (in Spanish)}

\section{Instrucciones Generales}

Bienvenidos. Queremos agradecerles por participar en esta actividad que durará aproximadamente una hora. Este tiempo incluye la explicación del ejercicio (35 minutos), el ejercicio como tal (10 minutos) y una corta encuesta al final (10 minutos). Tras finalizar la encuesta, le entregaremos sus ganancias del juego. Los fondos para cubrir estos gastos han sido proporcionados por la Universidad del Rosario.

Este es un juego de negociación donde usted y la persona con quién jugará han heredado una finca que deberán repartirse. También han heredado unas fichas que representan dinero. Ustedes pueden utilizar estas fichas en la negociación en caso que quieran quedarse con una mayor parte de la finca. A continuación explicaremos cómo se van a calcular sus ganancias según el número de fichas y el número de parcelas con las que quede al final del juego.

Las ganancias del juego no son un pago por participar, por lo que esperamos que participe en futuras actividades de otros investigadores así no haya un pago de por medio. Las ganancias del juego sirven para que sus decisiones tengan consecuencias económicas, y se parezcan más a las decisiones que toma en su vida diaria. Los otros participantes no sabrán durante o después del experimento nada sobre sus ganancias o sus respuestas en la encuesta.

Las reglas del juego pueden ser diferentes a las reglas que aplicaron cuando otros habitantes de este municipio participaron, por lo que los comentarios que usted haya podido escuchar no necesariamente aplican a este juego. Ahora podemos comenzar.

\section{Introducción: la repartición}

Este ejercicio busca entender las decisiones de producción y repartición de la tierra en \{nombre del municipio\}. Ustedes han heredado la finca "El Triángulo," que está compuesta de 9 parcelas pequeñas del mismo tamaño. Además, cada uno ha heredado 10 fichas.

(El monitor entrega el mapa triangular y las fichas)

Al final del juego, por cada parcela que tenga, se le entregará un dado.Si al final se queda con una parcela, recibirá un dado; si se queda con dos, se le entregarán dos, y así sucesivamente, hasta recibir nueve dados si se queda con nueve parcelas./ Si se queda toda la finca, con nueve parcelas, usted recibe nueve dados. Luego, los dados se van a lanzar, 
todos a la vez, dentro de una caja. El resultado del lanzamiento de los dados representará su producción total, la cual se verá traducida en fichas. Más adelante explicaremos las reglas adicionales de la producción.

Tener más parcelas implica mayor producción por lanzar los dados, pero deberá negociar cuántas fichas le da a su compañero por aceptar ese negocio. Usted podrá usar las 10 fichas para negociar la repartición de la finca con su compañero. Es posible que uno de ustedes se quede con toda la finca, o que encuentren una división de la finca.

Quedarse con todas, o la mayoría de parcelas es bueno porque va a recibir más dados, por lo que puede producir más fichas. Pero deberá negociar cuántas fichas, de las 10 que originalmente heredó, le dará a su compañero por aceptar ese arreglo.

Al final del juego usted recibirá $\$ 1.000$ (pesos colombianos) por cada ficha que tenga. Cuentan todas las fichas amarillas y todas las fichas de la producción tras lanzar los dados.

\section{Producción de la finca}

La producción de una parcela puede ser buena, mala o regular. Como no todas las personas producen la misma cantidad cuando trabajan la tierra, uno de ustedes va a tener dados grandes y el otro va a tener dados pequeños. Con el dado grande el producto de cada parcela puede ser de $[\mathbf{3}, \mathbf{4}$, ó $\mathbf{5} / \mathbf{2}, \mathbf{4}$, ó 6] fichas. Con el dado pequeño el producto de cada parcela puede ser de $[2,3$, ó $4 / 1$, 3, ó 5] fichas. Como cada número aparece dos veces en el dado, usted tiene la misma probabilidad de que la producción sea buena, mala o regular.

Ahora vamos a armar las parejas. Cada uno va a lanzar un dado de plástico. Las dos personas que saquen el número más grande serán la primera pareja, y las dos personas que saquen el número más pequeño serán la segunda pareja.

Ahora vamos a repartir los dados de producción. Cada uno va a lanzar de nuevo un dado de plástico. Quién saque el número más grande se quedará con el dado grande, y quién saque el número más pequeño se quedará con el dado pequeño.

(El monitor asigna a los participantes en grupos según los resultados del dado, y luego asigna los dados grandes y pequeños. El monitor entrega sólo un dado grande/pequeño a cada participante.)

\section{Costos de producción: agua}

Dos de los tres lados del triángulo tienen marcada una línea azul que simboliza una quebrada o un río que pasa por algunas parcelas de la finca. Una parcela tiene agua cuando uno de los lados de la parcela tiene la línea azul. En esos casos, en el centro de la parcela hay dibujada una gota de agua. Hay cinco parcelas con agua y cuatro parcelas sin agua.

En las parcelas con agua, el costo de producir es cero. En las parcelas sin agua, el costo de producir es 1. Cuando calculemos las ganancias, vamos a restarle una ficha por cada parcela sin agua. 


\section{Costos de producción: linderos}

Si deciden dividirse la finca, ustedes van a poner linderos que dividan las parcelas de cada uno. Cuando ustedes hagan una propuesta sobre cómo dividir la finca yo pondré una barra roja que marca por dónde pasa el lindero. Cada lindero le cuesta 1 ficha a cada uno. Cuando calculemos las ganancias, vamos a restarle una ficha por cada lindero que divida la finca.

(El monitor traza una división y pone sobre el mapa las barras rojas)

\section{Calcular las ganancias finales}

Usted recibirá $\$ 1.000$ (pesos colombianos) por cada ficha que tenga al final del juego. Hay dos formas de acumular fichas. Puede quedarse con las fichas que le fueron entregadas al inicio y pedirle más de esas fichas a su compañero durante la negociación. O usted también puede pedir parcelas y producir fichas adicionales lanzando los dados. Recuerde que reduciremos sus ganancias en una ficha por cada parcela sin acceso a agua y una fichas por cada lindero que divida la finca.

Este es un resumen de las instrucciones:

1. Marcar con la barra roja los linderos de la división que quieren negociar y decidir cuántas fichas intercambiarían por aceptar ese negocio.

2. Verificar la producción máxima y mínima de acuerdo con la división propuesta la finca.

3. Restar una ficha por cada parcela sin agua, y una por cada lindero.

4. Sumar las fichas de producción mínima y máxima después de los costos, y las fichas que le quedan después de negociar.

5. Multiplicar el total de fichas que le quedan por $\$ 1.000$ (pesos colombianos)

\section{Veamos un ejemplo}

[Vea la Figura A.3]

1. Usted tiene el dado grande y propone quedarse con 6 parcelas y entregar a cambio 3 fichas.

2. Su producción mínima por parcela es $[\mathbf{3}$ / 2] fichas, y su producción máxima es $[\mathbf{5} / \mathbf{6}]$ fichas. Con sus seis parcelas su producción mínima es [18 / 12] fichas, y su producción máxima es $[\mathbf{3 0} / \mathbf{3 6}]$ fichas.

3. Su costo de producción es de 5 fichas. Tres parcelas no tienen agua, y hay dos linderos.

4. Quitando las 5 fichas de sus costos, y las 3 fichas que le da a la otra persona, su total de fichas al final será de mínimo $[\mathbf{1 0}+\mathbf{1 8 - 5 - 3}=\mathbf{2 0} / \mathbf{1 0}+\mathbf{1 2 - 5 - 3}=\mathbf{1 4}]$, y máximo de $[10+30-8=32 / 10+36-8=38]$.

5. Sus ganancias estarán entre $[\$ 20.000$ and $\$ 32.000 / \$ 14.000$ and $\$ 36.000]$ (pesos colombianos) si aceptan este negocio. 


\section{¿Cómo se realiza la negociación?}

Ustedes tendrán 5 minutos para negociar. La conversación que ustedes tengan durante estos 5 minutos será grabada, pero nosotros no estaremos presentes. Esto nos ayudará a entender cuáles son los elementos más importantes en la negociación. Si llegan a un acuerdo antes de los 5 minutos por favor avísennos.

Cualquiera puede proponerle al otro un negocio. La negociación puede incluir una transferencia que sea igual o menor a las 10 fichas que cada uno recibió al inicio. Pueden llegar a un acuerdo en que la finca se divide, o no, y pueden usar o no las fichas como parte del acuerdo. Cuando termine el tiempo de negociación el jugador del dado grande propondrá cómo dividir la finca, y cuántas fichas entrega o pide. Nosotros lo registraremos en la hoja de contrato. Luego, el jugador del dado pequeño decide si acepta la propuesta. Si no la acepta, puede hacerle una contrapropuesta al compañero. En la contrapropuesta propondrá cómo dividir la finca, y cuántas fichas entrega o pide. Esta es la última oportunidad de que lleguen a un acuerdo.

\section{¿Qué pasa si luego de la contrapropuesta no llegan a un acuerdo?}

Cada uno mantiene sus fichas iniciales y se queda con dos parcelas con agua y dos parcelas sin agua (ver la Figura A.4). En esta asignación se pierde una de las nueve parcelas, que es equivalente a los gastos de un proceso judicial cuando no logran llegar a un acuerdo.

\section{Finalización del juego}

Yo llevaré a cada uno aparte y le entregaré un dado por cada parcela que posea. Cada uno lanzará los dados dentro de la caja, y solo los dos veremos el resultado. Su compañero no sabrá cuáles fueron los números que salieron en los dados y no conocerá su pago final.

(El coordinador pregunta si hay dudas.)

Si no hay preguntas vamos a leer en voz alta el consentimiento informado. Este es un documento en el que ustedes declaran que están aquí bajo su voluntad y que han entendido las instrucciones del juego, y nosotros declaramos que los datos serán utilizados de forma confidencial y con fines académicos.

(El coordinador lee el consentimiento informado.)

Si está de acuerdo, por favor firme el consentimiento informado que le ha sido entregado. 